\title{
Rehabilitating Jefferson Parish: Why Ties Without a Substantial Foreclosure Share Should Not Be Per Se Legal
}

\section{Citation}

Einer R. Elhauge, Rehabilitating Jefferson Parish: Why Ties Without a Substantial Foreclosure Share Should Not Be Per Se Legal (The Harvard John M. Olin Center for Law, Economics, and Business Discussion Paper No. 801, Nov. 2014).

\section{Permanent link}

http://nrs.harvard.edu/urn-3:HUL.InstRepos:16085411

\section{Terms of Use}

This article was downloaded from Harvard University's DASH repository, and is made available under the terms and conditions applicable to Other Posted Material, as set forth at http:// nrs.harvard.edu/urn-3:HUL.InstRepos:dash.current.terms-of-use\#LAA

\section{Share Your Story}

The Harvard community has made this article openly available. Please share how this access benefits you. Submit a story.

Accessibility 


\section{HARVARD}

JOHN M. OLIN CENTER FOR LAW, ECONOMICS, AND BUSINESS

\section{REHABILITATING JEFFERSON PARISH: WHY TIES WITHOUT A SUBSTANTIAL FORECLOSURE SHARE SHOULD NOT BE PER SE LEGAL \\ Einer Elhauge}

Forthcoming in Antitrust Law Journal (2015)

Discussion Paper No. 801

$11 / 2014$

Harvard Law School

Cambridge, MA 02138

This paper can be downloaded without charge from:

The Harvard John M. Olin Discussion Paper Series: http://www.law.harvard.edu/programs/olin_center/

The Social Science Research Network Electronic Paper Collection:

http://ssrn.com/abstract=2528605 


\title{
REHABILITATING JEFFERSON PARISH: WHY TIES WITHOUT A SUBSTANTIAL FORECLOSURE SHARE SHOULD NOT BE PER SE LEGAL
}

\author{
Einer Elhauge ${ }^{*}$ \\ 11/18/2014, forthcoming Antitrust Law Journal (2015)
}

\begin{abstract}
Current tying law uses a bifurcated rule of reason, condemning ties that have either tying market power or a substantial tied foreclosure share, absent an offsetting procompetitive justification. Many critics of tying law advocate overruling the first branch, commonly called the quasi per se rule, thus making all ties without a substantial foreclosure share per se legal. This article shows they are mistaken. Even without a substantial foreclosure share, ties with market power restrain competition in ways that are likely to harm both consumer welfare and total welfare as long as they foreclose a substantial dollar amount of sales. Critics claim that these effects do not legally count as anticompetitive because they do not impair rivals, but their claim conflicts with precedents that rule otherwise and with the principle that antitrust protects competition, not competitors. Both precedents and economics also show that critics are wrong in claiming that there is no valid distinction between setting a profit-maximizing price and extracting the remaining consumer surplus through tying agreements. Because even the critics admit that consumer welfare and total welfare are harmed by some ties with market power that lack a substantial foreclosure share, even their own analysis fails to support their position of per se legality for such ties. It would instead support the current doctrine that sorts out the ties with market power that harm consumer welfare from those that do not.
\end{abstract}

JEL Codes: C72, K21, L12, L40, L41, L42.

Keywords: tying, ties, antitrust, quasi per se, bundling, requirements ties, metering ties, price discrimination, extracting consumer surplus, consumer welfare, foreclosure share, Jefferson Parish.

\footnotetext{
* Petrie Professor of Law, Harvard Law School. I am grateful for helpful comments from Ian Ayres, Richard Brunell, Michael Carrier, Joshua Davis, Warren Grimes, Rebecca Haw, Scott Hemphill, Alex Krueger, Barry Nalebuff, Christopher Sagers, and Spencer Waller.
} 


\title{
REHABILITATING JEFFERSON PARISH: WHY TIES WITHOUT A SUBSTANTIAL FORECLOSURE SHARE SHOULD NOT BE PER SE LEGAL
}

\author{
(C) 2012-14 Einer Elhauge. All rights reserved.
}

In antitrust circles, it has long been fashionable to show how sophisticated one is by disdainfully dismissing old Supreme Court precedents that created per se rules based on noneconomic theories about protecting business autonomy. One by one, the per se rules against vertical nonprice restraints, vertical maximum price fixing, and vertical minimum price fixing have all been overruled because of economic critique, leaving many to assume that the quasi per se rule on tying would be the next domino to fall. ${ }^{1}$ However, the quasi per se rule on tying never really fit in this row of dominoes. There are three main reasons.

First, the quasi per se rule on tying has never truly been a per se rule, but rather is a form of rule of reason review that requires evidence of market power and considers offsetting procompetitive justifications, just like the typical rule of reason applied to vertical agreements. Moreover, as Part I shows, the elements of the quasi per se rule precisely fit the three economic theories about when ties without a substantial foreclosure share will harm consumer welfare by worsening price discrimination or extracting individual consumer surplus. Indeed, even if one (incorrectly) believed that the antitrust standard was total welfare, rather than consumer welfare, those elements would still identify ties that harm total welfare. ${ }^{2}$ The quasi per se rule is thus simply a structured rule of reason that correctly identifies the elements necessary to prove certain anticompetitive effects. Because those anticompetitive effects do not require a substantial foreclosure share, the fact that the quasi per se rule rejects making a substantial foreclosure share necessary to prove an anticompetitive tie does not reject the rule of reason approach, but rather simply applies the rule of reason correctly.

Second, the tying rule is the only rule on vertical agreements that critics are not trying to replace with a full rule of reason. Instead, they are trying to replace tying's quasi per se rule with a rule of per se legality for vertical tying agreements

\footnotetext{
${ }^{1}$ See, e.g., IX Phillip E. AREEDA \& Herbert HovenKAmP, ANTITRUST LAW 258-59 (3rd ed. 2011).

${ }^{2}$ Changing the antitrust standard from consumer welfare to total welfare would affect the general likelihood that ties meeting those elements would harm welfare and how strong the benefits would have to be to offset those harms, but would not change the elements themselves.
} 
that lack a substantial foreclosure share. ${ }^{3}$ In other words, although the former Chicago school view that all ties should be per se legal has seemingly been abandoned, it has been replaced with the quasi-Chicago view that all ties without a substantial foreclosure share should be per se legal. As Part II shows, even if one accepted the critics' mistaken claim that the likely welfare effects of such ties are positive, that claim would not support their position that ties without a substantial foreclosure share should be per se legal because the critics themselves acknowledge that such ties sometimes harm both consumer welfare and total welfare when tying market power exists. Nor would it support their critique of the quasi per se rule because (as some of them acknowledge) that rule allows defendants to introduce any procompetitive justification that would show a net increase in the relevant welfare standard.

Third, the quasi per se rule on tying is the one rule on vertical agreements that the Supreme Court reaffirmed during the modern age of antitrust economics, in its 1984 opinion in Jefferson Parish Hospital District No. 2 v. Hyde. ${ }^{4}$ Although Jefferson Parish has often been regarded as economically confused and internally inconsistent, Part III shows that this view is based on a major misreading of an opinion that is far more subtle and economically sophisticated than commonly recognized. In fact, Jefferson Parish rejected requiring a substantial foreclosure share based on each of the three economic theories for how ties with tying market power can create extraction or price discrimination effects that harm consumer welfare without a substantial foreclosure share. Nor are critics right that treating those extraction and price discrimination effects as anticompetitive conflicts with other language in Jefferson Parish. Some critics claim it conflicts with language that requires some restraint of competition in the tied market. However, those extraction and price discrimination effects cannot create any substantial harm to consumer welfare without restraining competition for a substantial dollar amount of tied sales, which is precisely what the quasi per se rule requires. Critics also claim that treating extraction and price discrimination effects as anticompetitive

\footnotetext{
${ }^{3}$ See Dennis W. Carlton \& Ken Heyer, Extraction v. Extension: The Basis for Formulating Antitrust Policy Towards Single-Firm Conduct, 4 COMPETITION POL'Y INT'L 285, 290-92 (2008); Dennis W. Carlton and Michael Waldman, Brantley Versus NBC Universal: Where's the Beef?, 8(2) COMPETITION POLICY INT'L $1,11-12$ (Autumn 2012); Daniel Crane, Tying and Consumer Harm, 8(2) CompeTiTiOn Policy InT'L 27, 27, 32-33 (Autumn 2012); Erik Hovenkamp \& Herbert Hovenkamp, Tying Arrangements and Antitrust Harm, 52 Ariz. L. Rev. 925, 927, 958, 966-67 (2010); Thomas A. Lambert, Appropriate Liability Rules for Tying and Bundled Discounting, 72 Ohio. St. L.J. 909, 913-14, 980 (2011); Steven Semararo, Should Antitrust Condemn Tying Arrangements That Increase Price Without Restraining Competition?, 123 HARV. L. REV. FORUM 30, 30-31 (2010). At least one critic would allow challenges without a substantial foreclosure share when two sellers horizontally agreed to enter into tying agreements, Crane, supra, at 27-28, 33, but that would not alter his rule of per se legality for vertical tying agreements that lack a substantial foreclosure share.

${ }^{4} 466$ U.S. 2, 12-14 (1984).
} 
conflicts with Jefferson Parish's conclusions that the quasi per se rule does not apply to ties that foreclose a single low-volume purchaser or an unwanted tied product. But Part III establishes that those conclusions actually fit well with situations where price discrimination or extraction effects are impossible or insubstantial.

More generally, critics argue that raising prices is indistinguishable from ties that expropriate through extraction and price discrimination effects, and thus they claim that condemning such ties conflicts with language in Jefferson Parish and other cases that observes it is not anticompetitive to simply raise prices. However, as Part III shows, Jefferson Parish expressly_and correctly-distinguished the two at length, citing precisely the three extraction and price discrimination effects I detail. Moreover, modern economic literature proves that the Court was correct to draw the distinction it did, because firms have the optimal incentives to invest in productive efforts to create market power if they get only a fraction of total surplus. The Court's distinction maintains that fraction by entitling firms to receive only the normal supracompetitive profits from setting a profit-maximizing price, rather than obtaining all of total surplus by extracting the remaining consumer surplus through tying agreements.

Nor is Jefferson Parish anomalous or a relic of the past. The same connection between the quasi per se rule and extraction and price discrimination effects was explicitly reaffirmed in 1992 by even the conservative dissenting opinion in Eastman Kodak Co. v. Image Technical Services, Inc. ${ }^{5}$ Also, Jefferson Parish's doctrinal conclusions were confirmed in 2006 by Illinois Tool Works $v$. Independent Ink, Inc., ${ }^{6}$ which also confirmed that it regarded this quasi per se approach as a form of rule of reason analysis that rejected a per se rule.

\section{Why Tying’s Quasi Per Se Rule Fits the Economic Literature}

Current tying law employs a bifurcated rule of reason. The first branch condemns ties that foreclose a substantial dollar amount of sales if there is tying market power and no offsetting procompetitive justification. ${ }^{7}$ This branch goes under the unfortunate misnomer of the "quasi-per se rule," but it is plainly a form of rule of

\footnotetext{
5504 U.S. 451 (1992).

${ }^{6} 547$ U.S. 28 (2006).

${ }^{7}$ Einer Elhauge, Tying, Bundled Discounts, and the Death of the Single Monopoly Profit Theory, 123 Harv. L. Rev. 397, 420, 425 (2009) [hereinafter Elhauge, Tying]; EINER ElHAUGE, United STATES ANTITRUST LAw \& ECONOMICS 368-71 (2d ed. 2011) [hereinafter ElHAUGE, U.S. ANTITRUST]. Under either branch, a tie by definition also requires a tying condition and separate products. Id. at 369-70.
} 
reason review. The quasi per se rule's basic structure - basing liability on market power and the absence of any offsetting procompetitive justification - parallels the general rule of reason standard for judging any horizontal or vertical restraint that does not fall within a per se rule. Indeed, the Supreme Court has stressed that it views its quasi per se rule as "rejecting" the prior "per se" rule because the quasi per se rule requires market power and "rejected" the position that ties rarely have any procompetitive justification. ${ }^{8}$ The second branch of the bifurcated rule of reason condemns ties that foreclose a substantial tied market share and lack an offsetting procompetitive justification. ${ }^{9}$ This is also a form of rule of reason review, one that parallels the rule of reason used for exclusive dealing.

Today, there seems to be little controversy about the second branch. Even critics of current tying doctrine concede that ties can be anticompetitive when they create a substantial tied market foreclosure share. ${ }^{10}$ No one seems to still contend that the single monopoly profit theory holds and justifies a rule of total per se legality for all ties. That theory, at least, now seems good and buried. But many critics of current tying law argue that the Supreme Court should jettison the first branch of tying law's bifurcated rule of reason, which infers anticompetitive effects from tying market power rather than from a substantial tied foreclosure share. ${ }^{11}$ Because these critics would limit rule-of-reason analysis to ties with a substantial tied foreclosure share, their position would create a rule of per se legality for all ties lacking a substantial tied foreclosure share.

This Part shows that, contrary to the claims of critics, the quasi per se branch of current tying law is well-grounded in the economic literature. That literature proves that ties without a substantial foreclosure share can have three possible anticompetitive effects: (1) intra-consumer surplus extraction; (2) inter-product price discrimination; and (3) intra-product price discrimination. As detailed below each of these effects involve restraints on competition to the affected buyers that can-and usually do-reduce both consumer welfare and total welfare. A

\footnotetext{
${ }^{8}$ Illinois Tool Works, 547 U.S. at 36, 42, 45.

${ }^{9}$ Elhauge, U.S. Antitrust, supra note, at 370-71. Direct proof that the competitiveness of tied market rivals was impaired would obviate the need to prove a substantial tied foreclosure share under this second branch, because a foreclosure share is simply used to infer those anticompetitive effects. FTC v. Ind. Fed'n of Dentists, 476 U.S. 447, 460-61 (1986); ElHAUGE, U.S. ANTITRUST, supra note, at 370-71; Elhauge, Tying, supra note, at 473. As shorthand, I will use "ties without a substantial foreclosure share" to refer to ties for which the evidence fails to establish either a substantial tied foreclosure share or direct proof that the competitiveness of tied market rivals was impaired.

${ }^{10}$ See, e.g., Carlton \& Heyer, supra note, at 298; Carlton \& Waldman, supra note , at 9-11; Crane, supra note , at 28; Hovenkamp \& Hovenkamp, supra note , at 956; Lambert, supra note , at 913-14, 980; Semararo, supra note , at 31 .

${ }^{11}$ See supra note
} 
consumer welfare standard judges a restraint of trade by whether it harms consumers, whereas a total welfare standard would allow a restraint of trade if it increases monopoly profits by more than it harms consumer welfare. Although consumer welfare is and should be the legal standard, ${ }^{12}$ throughout the following analysis I also address total welfare because critics of current tying law often mistakenly assume or argue that the legal standard is or should be total welfare,

As shown below, each of the above three anticompetitive effects require market power in the tying product. None of them depend on having a substantial foreclosure share in the tied market, although each of them requires foreclosing some sales in the tied market. These three anticompetitive effects thus correspond perfectly to the quasi-per se branch of tying doctrine's bifurcated rule of reason, which requires proof of tying power and a substantial dollar amount of foreclosed sales, but does not require proof of a substantial foreclosure share.

My baseline analysis of total welfare effects assumes the best case for critics by conservatively assuming there is zero dissipation of the additional profits earned from tying. In reality, as explained below, there is almost certainly some profit dissipation because tying imposes enforcement costs and because any increased profit margins will likely increase both management agency costs (ex post) and expenditures to obtain such market power positions (ex ante). To the extent that such profit dissipation occurs, then ties are even more likely to reduce total welfare than my baseline analysis indicates. To the extent one believes that all these profits will be dissipated (as Richard Posner once argued for ex ante expenditures), then the total welfare results become the same as the consumer welfare results.

My baseline welfare analysis also assumes that the ties at issue have no special procompetitive justification. I do so because this baseline is the correct one to assess the critics' claim that ties without a substantial foreclosure share should be per se legal even when no procompetitive justification has been proven. If such justifications do exist in a particular case, they are admissible under the quasi per se rule, and they can and should eliminate liability when they fully offset any anticompetitive effects indicated by the baseline analysis. ${ }^{13}$

\footnotetext{
${ }^{12}$ See Elhauge, Tying, supra note, at 436-442 (collecting cases showing that the legal standard is consumer welfare and reasons why that standard makes policy sense); ELHAUGE, U.S. ANTITRUST, supra note , at 632-34 (summarizing literature indicating that the total welfare objective can actually be advanced better by applying a consumer welfare test than a total welfare test).

${ }^{13}$ Critics often try to bolster the baseline welfare analysis by pointing out tying can often have procompetitive justifications. Carlton \& Waldman, supra note , at 2, 8-9; Hovenkamp \& Hovenkamp, supra note , at 958-961, 96465; Lambert, supra note, at 940-41. That is certainly true, but the possibility of procompetitive justifications cannot support the critics' position of per se legality for ties lacking a substantial foreclosure share because their position
} 
Critics of tying doctrine generally focus on metering ties, where buyers purchase multiple units of the tied product to use with a tying product. However, many ties involve cases where purchases of the tied product do not meter usage of the tying product, and where buyers either purchase multiple units of the tying product or purchase the products in a fixed ratio. Because the economics of such ties are simpler and often ignored, I begin with them before addressing metering ties.

\section{A. Intra-Consumer Surplus Extraction Where Multiple Units of the Tying Product Are Purchased}

The Economic Effects and Necessary Conditions. Suppose each individual consumer of a product purchases multiple units of that product from a firm that has market power. Because each individual consumer will get declining value from each additional unit, each will have a downward-sloping demand curve. The firm will thus choose its profit-maximizing price given those individual demand curves. Each individual consumer will keep buying units until it gets to the marginal unit whose value matches that price. For all the prior (or inframarginal) units, each individual consumer will enjoy some value in excess of that price, which gives each individual a positive consumer surplus.

That firm can use a tie to extract that individual consumer surplus, as was first shown by Professor M.L. Burstein, whose work we shall see was specifically relied on by the Supreme Court to justify the quasi-per se rule. ${ }^{14}$ The firm need simply tie the sale of this (tying) product to an obligation to buy another (tied) product from it at an elevated price. As long as the consumer surplus lost from buying the tied product at an elevated price is less than the consumer surplus enjoyed by buying the tying product at its profit-maximizing price, the consumer will accept the tie. ${ }^{15}$

would legalize such ties even without any procompetitive justifications. Instead, the possibility that such ties have procompetitive justifications supports the quasi per se rule approach of allowing proof that such procompetitive justifications offset any adverse baseline effects from ties with market power. See infra Part II.

${ }^{14}$ See M.L. Burstein, The Economics of Tie-In Sales, 42 REV. ECON. \& STAT. 68, 68-69 (1960) [hereinafter Burstein, Tie-In Sales]; M.L. Burstein, A Theory of Full-Line Forcing, 55 NW. U. L. REV. 62, 73-91 (1960) [hereinafter Burstein, Full-Line Forcing]. See also Elhauge, Tying, supra note , at 407-413; Economides, Tying, bundling, and loyalty/requirement rebates 121, at 127-129, in RESEARCH HANDBOOK ON THE ECONOMICS OF ANTITRUST LAW (Edward Elgar Publishing Ltd. 2012).

${ }^{15}$ This is sometimes called "intra-consumer price discrimination" because it aims to achieve effects similar to charging each consumer a different price for each unit it buys, depending on the marginal value of that unit. 
To illustrate, suppose a monopolist in printers that cost $\$ 200$ to make also sells lamps that cost $\$ 20$ to make in a competitive market to 10,000 businesses that use both printers and lamps in their offices. Each business values the first printer they buy at $\$ 1000$ but values each additional printer they buy $\$ 1$ less, so they would value their $400^{\text {th }}$ printer at $\$ 600$ and their $800^{\text {th }}$ printer at $\$ 200$. Each business also values the first lamp they buy at $\$ 80$, and values each additional lamp 10 cents less, so they value their $300^{\text {th }}$ lamp at $\$ 50$ and their $600^{\text {th }}$ lamp at $\$ 20$. Without tying, the lamps would be sold at their competitive price of $\$ 20$, and each buyer would enjoy consumer surplus on lamps of $(1 / 2)(\$ 80-\$ 20)(600)=\$ 18,000$. The printer monopolist would maximize profits by selling printers for $\$ 600$, thus selling 400 printers to each business. Each buyer would enjoy consumer surplus on printers of $(1 / 2)(\$ 400)(400)=\$ 80,000$. The total consumer surplus for all buyers in both markets would thus be $(\$ 98,000)(10,000)=\$ 980$ million. Profits would $\$ 0$ on lamps and $(\$ 400)(400)(10,000)=\$ 1.6$ billion on printers. So total welfare, the sum of profits plus consumer welfare, would be $\$ 2.58$ billion without tying.

With tying, the printer monopolist ties printers at $\$ 600$ to a requirement to buy lamps from it at $\$ 50$. Those prices maximize profits because they equal the monopoly price for each product. Consumer surplus for each buyer is $\$ 80,000$ on printers and $(1 / 2)(\$ 50-\$ 20)(300)=\$ 4,500$ on lamps, or $\$ 84,500$. Each thus suffers a loss of consumer surplus, but each accepts the tie because $\$ 84,500$ is much higher than the $\$ 18,000$ in surplus each would get by rejecting the tie and buying only lamps at their competitive price of $\$ 20$. Other way to think of it is that the tie threatens each buyer with a loss of $\$ 80,000$ surplus on printers unless they agree to lose $\$ 13,500$ in surplus on lamps, and because the former exceeds the latter, each buyer accepts the tie. The total consumer surplus for all buyers in both markets would thus be $(\$ 84,500)(10,000)=\$ 845$ million. Profits on printers would be $\$ 1.6$ billion and on lamps would be $(\$ 50-20)(300)(10,000)=\$ 90$ million, for a total of $\$ 1.69$ billion, making it profitable to tie. Total welfare would be $\$ 2.535$ billion, which is lower than without tying.

Thus, here the tie reduces both consumer welfare and total welfare. Moreover, the tie does leverage monopoly profits in one product into monopoly profits in two products. Notice that the buyers in this market do not differ from each other, so discriminating between buyers is not possible and cannot be facilitated by this tie. Instead, the tie is extracting intra-consumer surplus by taking advantage of the fact that each buyer's valuation of the tying product declines the more units of it they buy. 
More generally, such ties restrain competition for tied product sales in a way that always lower consumer welfare because they extract individual consumer surplus. Such ties also violate the total welfare standard whenever the buyers who are subject to the tie value the tying product significantly more than the tied product. With linear demand curves with the same slope, total welfare declines if the valuecost difference on the first unit purchased is $33 \%$ higher for the tying product than for the tied product. ${ }^{16}$ This condition seems likely to be met for most litigated ties, which generally involve a tying product that the buyers value significantly more than the tied product.

This anticompetitive effect requires the firm to have market power in the tying product and causes significant effects only if the tie forecloses a substantial amount of tied sales, but the effect in no way depends on having a substantial foreclosure share in the tied product market. The buyers subject to the tie could make up only $1 \%$ of the tied market, and the same effects would follow.

However, such a tie is possible only when buyers purchase multiple units of the tying product and do not purchase the two products in a fixed ratio. The reason is that, if buyers instead bought only one unit of the tying product or bought the two products in a fixed ratio, then the obligation to buy the tied product at an elevated price is equivalent to a price increase on each unit bought of the tying product and will cause buyers to purchase buy fewer units of the tying product. ${ }^{17}$ In contrast, when buyers purchase multiple units of a tying product that is not used or sold in any fixed ratio to the tied product, then the obligation to purchase the tied product at elevated prices does not alter the marginal price of buying additional units of the tying product.

The Weak Critique. Critics of tying law have largely ignored this anticompetitive effect. To the extent they have considered it, their arguments are quite unpersuasive. Erik and Herbert Hovenkamp admit that this effect can harm consumer welfare and total welfare, but they simply assert that there is no basis for thinking it would usually do so. ${ }^{18}$ However, they provide no analysis to support that assertion, which conflicts with the economic literature summarized above, which proves that this effect always decreases consumer welfare and also decreases total welfare in the typical case where the tying product is significantly

\footnotetext{
${ }^{16}$ See Elhauge, Tying, supra note, at 412; Patrick Greenlee, David Reitman \& David S. Sibley, An Antitrust Analysis of Bundled Loyalty Discounts, 26 INT'L J. INDUS. ORG. 1132, 1137, 1151 (2008).

${ }^{17}$ See Elhauge, Tying, supra note, at 409; Frank Mathewson \& Ralph Winter, Tying as a Response to Demand Uncertainty, 28 RAND J. ECON. 566, 570 (1997).

${ }^{18}$ Hovenkamp \& Hovenkamp, supra note, at 956.
} 
more valuable. Moreover, even if their assertion were correct, it would not support their conclusion that the "great majority" of ties do not harm consumer welfare or total welfare. ${ }^{19}$ Paul Seabright acknowledges that this effect can extract individual consumer surplus. $^{20}$ However, he assumes that this effect necessitates a requirements tie - that is, a tie requiring the buyer to make all its tied product purchases from the defendant - and asserts that requiring a buyer to buy exclusively from a seller is "rarely seen outside of gangster life." 21 He is mistaken on both scores: the economic literature shows that this effect does not necessitate a requirements tie, ${ }^{22}$ and requirements ties are actually commonplace, including in at least seven Supreme Court tying cases. ${ }^{23}$ Thomas Lambert also admits that this effect extracts consumer surplus, but asserts that anything that increases a seller's profits must increase its incentives to invest in innovation in a way that increases welfare in the long run. ${ }^{24}$ His argument is wrong on the economics and has been rejected by the Supreme Court for reasons detailed in Part III.

\section{B. Inter-Product Price Discrimination Even With Fixed Bundles}

The Economic Effects and Necessary Conditions. Suppose different buyers have varying demand for two products and that a firm has market power in both products. Without a tie, the firm will set a profit-maximizing price for each product that reflects the market demand curve for that product. Consumers of each product who value the products above their respective separate prices will enjoy consumer surplus. A firm can use a tie to expropriate some of that consumer surplus across both products, as was first shown by Professor George Stigler, whose work we shall see was also specifically relied on by the Supreme Court to justify the quasi-per se rule. ${ }^{25}$

To illustrate, suppose we have 10 million consumers whose valuation of the Reality Television Network and the Highbrow Television Network ranges linearly from $\$ 0$ to $\$ 10$. Suppose further that their valuations are negatively correlated, so

\footnotetext{
${ }^{19}$ Id. at 927.

${ }^{20}$ Paul Seabright, The Undead? A Comment on Professor Elhauge's Paper, 5(2) COMPETITION POL'Y INT'L 243, 244 (2009).

${ }^{21}$ Id. at 247.

${ }^{22}$ Elhauge, Tying, supra note , at 409; Jose Carbajo et al., A Strategic Motivation for Commodity Bundling, 38 J. INDUS. ECON. 283, 284 (1990).

${ }^{23}$ Illinois Tool Works, 547 U.S. at 32; Kodak, 504 U.S. at 458; Jefferson Parish, 466 U.S. at 4-5; Int'1 Salt Co., Inc. v. United States, 332 U.S. 392 (1947); Int'l Bus. Machs. Corp. v. United States, 298 U.S. 131 (1936); United Shoe Mach. Co. v. United States, 258 U.S. 451, 456 (1922); Motion Picture Patents Co. v. Universal Film Mfg. Co., 243 U.S. 502 (1917).

${ }^{24}$ Lambert, supra note, at 921.

${ }^{25}$ See George J. Stigler, United States v. Loew's Inc.: A Note on Block-Booking, 1963 SUP. CT. REV. 152.
} 
that consumers who value Reality Television highly tend to put a low value on Highbrow Television, and vice versa. Specifically, consumers who value one network at $\$ 10$ value the other at $\$ 0$, consumers who value one network at $\$ 9$ value the other at $\$ 1$, and so on, with the sum of each consumer's valuation for both networks always adding up to $\$ 10$. Assume a constant marginal cost of zero. Without tying, the firm would maximize profits by setting the price for each network at $\$ 5$, and the 5 million consumers who valued each network above $\$ 5$ would buy it and get positive consumer surplus, adding up to a total of $\$ 25$ million in consumer surplus across both networks. With tying, the firm would instead charge $\$ 10$ for a bundle of the two networks, leaving each consumer with zero consumer surplus and harming consumer welfare by $\$ 25$ million.

This effect is called inter-product price discrimination because it aims to achieve results similar to price discrimination across both products. Although Stigler (like the above example) assumed a negative demand correlation, subsequent work has proven that the same sort of effect follows even with a positive demand correlation as long as the positive correlation is not too strong. ${ }^{26}$ Further, Professor Schmalensee proved that, given any normal distribution of buyer values, such a tie always reduces consumer welfare. ${ }^{27}$ If the two bundled products have symmetric demand curves, he proved such a tie also violates the total welfare standard unless the strength of demand relative to cost is "especially high." 28 Moreover, if the bundled products have asymmetric demand curves, he proved such ties are even more likely to reduce total welfare. ${ }^{29}$ It thus seems likely that ties that cause interproduct price discrimination usually lower total welfare.

In short, assuming a normal distribution of buyer values, ties that create interproduct discrimination restrain competition in a way that always lower consumer welfare and usually lowers total welfare. Unlike intra-consumer surplus extraction, this effect is possible even if each buyer purchases at most a single unit of each product and even if the tie involves a fixed ratio. However, this effect cannot exist if there is a strong positive demand correlation between the two products, which means it is not possible if the two products are useless without each other. This effect also requires that the seller has some degree of market

${ }^{26}$ See Elhauge, Tying, supra note, at 405-06 (summarizing economic literature); Economides, supra note , at 129 (same).

${ }^{27}$ Richard Schmalensee, Gaussian Demand and Commodity Bundling, 57 J. BUS. S211, S221-23, S229 (1984).

${ }^{28} I d$. at $\mathrm{S} 221$.

${ }^{29}$ Id. at S218, S223. 
power in both products, rather than just in one of them. ${ }^{30}$ And it cannot extract significant amounts of consumer surplus unless it forecloses a substantial amount of sales. But this effect does not at all depend on foreclosing a substantial share of either market. The tie could be applied to only $1 \%$ of buyers in both markets, and the same effects would follow for that set of buyers.

The Mistaken Critique. Tying-law critics have disputed this effect, but they rely on unrealistic hypotheticals and even those hypotheticals do not support their conclusions. Erik and Herbert Hovenkamp admit that this effect could harm consumer welfare and total welfare, but they assert-based on a single hypothetical - that there is no reason is think that such adverse effects are likely. ${ }^{31}$ Even if that were true, it would not support their ultimate conclusion that the "great majority" of ties have no adverse welfare effects. ${ }^{32}$ Dennis Carlton and Michael Waldman also admit that this effect could decrease consumer welfare but use two hypotheticals to argue that it will not "necessarily" do so. ${ }^{33}$ Even if one accepts this conclusion, it does not justify their claim that their analysis "contradicts" the position that this effect "typically reduces consumer welfare." 34 An effect can typically reduce welfare without necessarily doing so in all cases.

Moreover, the only support that the Hovenkamps or Carlton and Waldman provide for their assertion that this effect is just as likely to increase consumer welfare consists of unrealistic hypotheticals that assume the implausible baseline that consumers enjoy zero consumer surplus without tying. In their hypotheticals, consumers have oddly discontinuous preferences; for example, the most nuanced of these hypotheticals assumes that consumers value the tied products at $\$ 1, \$ 2$ or $\$ 12$, but no consumer values the products at anything in between, while the other hypotheticals assume consumers only value the products at two discrete price points. $^{35}$ Further, because of the particular numbers used in their hypotheticals, they assume that non-tying firms sell only to the highest-valuing consumers in the market at a price that precisely equals their valuation, which is what creates the baseline that consumers receive zero consumer surplus without tying. ${ }^{36}$ These two features are related because under the ordinary assumption of continuous consumer preferences, a firm would pick the prices along that continuum that maximizes (1982)

${ }^{30}$ See Richard Schmalensee, Commodity Bundling by Single-Product Monopolies, 25 J.L. \& ECON. 67, 67-69

${ }^{31}$ Hovenkamp \& Hovenkamp, supra note , at 956.

${ }^{32}$ Id. at 927.

${ }^{33}$ Carlton \& Waldman, supra note, at 7.

${ }^{34} \mathrm{Id}$. at 8 .

${ }^{35}$ Id. at 5-6; Hovenkamp \& Hovenkamp, supra note , at 957.

${ }^{36}$ Carlton \& Waldman, supra note, at 6; Hovenkamp \& Hovenkamp, supra note , at 957. 
profits, thus necessarily leaving consumers who valued the products more highly on that continuum with positive consumer surplus. Their hypotheticals thus tell us nothing about the results under the more realistic assumption that consumers have a continuum of preferences. All their hypotheticals tell us is that, if you assume consumers receive zero consumer surplus without tying, then - not surprisingly tying cannot decrease consumer surplus because none ever existed. But this assumption of zero consumer surplus without tying is an artificial assumption that tracks no real-world markets and that slants the argument in favor of such ties. The ability to imagine such unrealistic examples hardly rebuts Schmalensee's proof that, under the sort of normal distributions generally assumed in social science, this effect always decrease consumer welfare.

Carlton and Waldman acknowledge that Schmalensee's proof shows that ties that create inter-product price discrimination decrease consumer welfare when demand is "symmetric", but they incorrectly claim that Schmalensee did not extend his analysis to cases where "demands are not symmetric across products, and therefore Schmalensee's results do not necessarily apply in those situations." 37 In fact, Carlton and Waldman have things backwards. Schmalensee not only does analyze the case without symmetric demand, but also shows that: "If symmetry does not hold, pure bundling is less likely to be ... welfare enhancing". ${ }^{8}$ Specifically, Schmalensee finds that asymmetric demand does not alter the conclusion that bundling always decreases consumer welfare but makes it more likely that bundling also reduces total welfare. ${ }^{39}$

Thomas Lambert concludes that while ties that induce inter-product price discrimination can reduce consumer welfare and total welfare, they "typically enhance total welfare". ${ }^{40}$ However, even if that were so, it would not rebut the proof that such ties harm consumer welfare, which is the actual legal standard. Even if the legal standard were changed to total welfare, his total welfare claim rests on the empirical assertion that most such ties involve two products whose demand is very high compared to their cost. ${ }^{41}$ As noted above, when that is true and the two demand curves are sufficiently symmetrical, then such ties do increase total welfare. But Lambert provides no empirical evidence that this is generally true in cases condemned by current tying doctrine. Further, to the extent that his empirical claim is valid, it indicates an output-increasing efficiency that offsets the

\footnotetext{
${ }^{37}$ Carlton \& Waldman, supra note, at $8 \&$ n. 8.

${ }^{38}$ Schmalensee, Gaussian Demand, supra note, at S218 (emphasis added).

${ }^{39} \mathrm{Id}$. at S223. The conclusion on consumer welfare is based on computer analysis. Id. at S213.

${ }^{40}$ Lambert, supra note, at 920, 934.

${ }^{41}$ Id. at $950-53$.
} 
inefficiencies that are created by the fact that such ties reallocate some output to buyers who value it less than the buyers who would have gotten the products without the tie. ${ }^{42}$ The quasi per se rule condemns ties only when they lack such an output-increasing efficiency that offsets the harm under the legal welfare standard. $^{43}$ Thus, even if the legal standard were changed to total welfare, total welfare would decline in any case actually condemned by the quasi per se rule.

\section{Intra-Product Price Discrimination from Metering Ties}

The Economic Effects and Necessary Conditions. Now suppose buyers purchase one product over which a firm has market power and another product that they use with the first product. If the firm simply charged a profit-maximizing price for the first product, then consumers who value that product above that price would enjoy consumer surplus.

That firm can use a tie between the products to take away consumer surplus on the first product, as was first shown by Professor Ward Bowman in work that we shall see was also cited by the Supreme Court to justify the quasi-per se rule. ${ }^{44}$ The firm need simply tie the sale of the product over which it has market power to an obligation to buy the other product from it at an elevated price. As long as the usage of that other product is correlated with demand for the first product, then this will effectively allow the firm to charge more to buyers who tend to have higher demand for the tying product.

For example, if buyers who print a lot tend to value printers more than those who print less, then tying the sale of printers to high-priced cartridges will effectively charge a higher price to buyers who tend to value printers more. In these cases, ties serve as a metering device to measure usage, in order to allow price discrimination that correlates with varying buyer valuation of the tying product. It is called intra-product price discrimination because it aims to achieve effects similar to charging different prices to different buyers of the tying product.

Perfect price discrimination, which charges each buyer the price for the tying product that equals its valuation of that product, clearly reduces consumer welfare (by taking all consumer surplus), but increases total welfare (by allowing sales of the tying product to anyone who values it at or above its marginal cost). However,

\footnotetext{
${ }^{42}$ Id. at 920, 950; Elhauge, Tying, supra note , at 406-07 (summarizing economic literature).

${ }^{43}$ See infra Part II.

${ }^{44}$ Ward S. Bowman, Jr., Tying Arrangements and the Leverage Problem, 67 YALE L.J. 19, 23-24, 33 (1957).
} 
ties cannot produce perfect price discrimination because, although charging based on usage tends to correlate with buyer valuations of the tying product, that correlation is imperfect because those buyer valuations turn not only on the amount of usage, but also on how much the buyer values each usage. If a buyer uses the tying product a lot but has a per-usage valuation that is lower than the elevated tied product price, the tie will prevent the buyer from buying the tying product even though the buyer's valuation of the tying product may be relatively high. Thus, a tie will inefficiently reallocate some output from buyers whose per-usage valuation is low to those for whom it is high, even when the former buyers use the tying product more heavily and thus derive more total value from the tying product. Perfect price discrimination would not create this reallocation effect because it results in sales to all buyers who value the tying product above marginal cost.

The economic literature proves that metering ties lower both consumer welfare and total welfare unless they increase output of the tying product. ${ }^{45}$ This proof justifies at least putting the burden on defendants to prove that their metering tie had some output-increasing efficiency, even though such an efficiency would not suffice to show the metering tie increases either form of welfare. The economic literature also shows that if the rate at which consumers desire to use the tying product is distributed either uniformly or log-normally, then metering ties always lower consumer welfare. ${ }^{46}$ If the desired usage rate is distributed uniformly, then metering ties lower total welfare if the minimum desired usage rate is $28.5 \%$ or higher of the maximum usage rate, but raises total welfare if the minimum usage rate is lower. ${ }^{47}$ If the desired usage rate is distributed lognormally, then even if the minimum desired usage rate is zero, metering ties lower total welfare absent a very large dispersion in desired usage, higher than $78 \%$ of the mean. The Appendix to this paper further shows that if the desired usage rate follows a simple normal bellshaped distribution with a minimum of zero, then metering ties always lower consumer welfare and also lower total welfare unless the standard deviation exceeds $40 \%$ of the mean.

${ }^{45}$ See Elhauge \& Nalebuff, The Welfare Effect of Metering Ties at __ (on file with author) (providing a formal proof); Elhauge, Tying, supra note, at $431 \& \mathrm{n} .89$ (making the same point conceptually without a formal proof).

${ }_{46}^{4}$ Id. at _ (proof for lognormal distribution); Elhauge, Tying, supra note , at 433, 481 (proof with uniform distribution); Barry Nalebuff, Price Discrimination and Welfare, 5(2) Competition Policy Int'1 221, 225-27, 235-36 (2009) (same).

${ }^{47}$ See Elhauge \& Nalebuff, supra note, at _. For example, if consumer usage of printers is uniformly distributed from a minimum of 290 to a maximum of 1000 , then a metering tie would reduce total welfare because the minimum usage is $29 \%$ of the maximum usage. Some minimum usage of a capital good like a printer makes sense because someone who planned to print just a few times would probably find it cheaper to bring their few print jobs to Kinkos or an office or friend. 
In short, any neutral assumption about the distribution of desired usage rates shows that metering ties lower consumer welfare. Whether metering ties lower total welfare depends partly on what sort of distribution one assumes. There are strong reasons to assume a normal distribution is usually more realistic than a uniform distribution. In most things in life, extreme preferences are less common that medium preferences. There might exist some buyers would use a printer only once at competitive prices, and other buyers who would use it a million times, but it would be surprising if such buyers were equally likely as buyers who would use their printer more moderately. Generally in social science, it is regarded as more realistic to assume that human characteristics have some sort of normal distribution, which here would mean that buyers who would use the printer a medium number of times are more plentiful than buyers who would use a lot or a little.

The proofs finding that metering ties are more likely to reduce total welfare with some form of a normal distribution reflect the fact that such a distribution means there are proportionally fewer low-usage buyers who would not buy the tying product at a uniform separate price but might with a tie. This is important because, as noted above, metering ties can increase total welfare only they increase tying product output, which requires increasing tying product sales to low-usage buyers enough to offset the inefficient allocation created by metering ties. Thus, if there are proportionally fewer low-usage buyers, metering ties cannot increase sales to low-usage buyers as much and are more likely to reduce total welfare. The more dispersed the desired usage rate, the flatter the normal curve, making it more similar to a uniform distribution rate and thus more likely to result in an increase in total welfare. (This same driving force explains why metering ties reduce total welfare even with a uniform distribution if the desired minimum usage rate is $28.5 \%$ or more than the highest usage rate.) 
With a normal distribution, because $68 \%$ of the population will fall within any standard deviation, then the metering ties will lower total welfare if we think at least $68 \%$ of buyers desire to use the tying product at between $60 \%$ to $140 \%$ of the mean usage. Standard deviations in that range may well describe the range of product usage for most markets. By way of comparison, a standard deviation of more than $40 \%$ for IQ would mean that more than $32 \%$ of people would have an IQ lower than 60 or higher than 140, and for height would mean that more than $32 \%$ of US men would have a height shorter than 3 feet 6 inches or higher than eight feet 2 inches. With a lognormal distribution, desired usage rates would have to be even more dispersed for a metering tie to avoid lowering total welfare. There is thus a sound basis for concluding that metering ties usually lower total welfare, unless one can show a very flat distribution of desired usage rates.

Creating the sort of intra-product price discrimination that lowers consumer welfare and (usually) total welfare requires tying market power, but it does not require a substantial foreclosure share. It would not matter if, for example, the tie affects only $1 \%$ of the tied market. However, a tie can have this effect only if buyers purchase varying amounts of the tied product and usage of the tied product positively correlates with valuation of the tying product. A fixed-ratio tie thus cannot have this effect.

The Erroneous Critique. Contrary to the above summarized economic literature, Erik and Herbert Hovenkamp argue that the "great majority" of metering ties (which they call "variable proportions" ties) benefit both consumer welfare and total welfare, and indeed "only harm consumer welfare in the most flagrant situations." enhance total welfare" and "most instances of metering enhance consumer welfare." model, on which Lambert relies. But neither the analogy nor the model actually supports their conclusions.

The analogy on which the Hovenkamps and Lambert rely is that ties are more similar to second-degree price discrimination than to third-degree price discrimination because ties offer the same price schedule to all buyers (like second-degree price discrimination) rather than directly pricing differently to

\footnotetext{
${ }^{48}$ Hovenkamp \& Hovenkamp, supra note, at 925, 928. See also id. at 927 ("consumers likely benefit most of the time"). Because proportions also vary for ties that involve intra-consumer surplus extraction, I find it more precise to use a term "metering ties" to indicate ties where variation in purchases of the tied product meter usage of the tying product.

${ }^{49}$ Lambert, supra note, at 934, 939.
} 
different buyers (like third-degree price discrimination). ${ }^{50}$ They concede that "Third-degree price discrimination that does not increase output necessarily decreases welfare" because it "transfers output from higher-value to lower-value customers." However, they assert that: "Second-degree price discrimination does not have this effect" because it offers everyone the same price schedule. ${ }^{52}$ They then conclude by analogy that ties cannot reduce welfare by reallocating tying product output from higher-value to lower-value customers and thus can increase welfare without increasing tying product output. ${ }^{53}$

However, this analogy does not help their argument. To begin with, even if their analogy held, their claim that second-degree price discrimination generally benefits consumer welfare conflicts with the literature they cite for that proposition, ${ }^{54}$ as well as with some of their own work. ${ }^{55}$ As for total welfare, it is not the antitrust standard, and any claim about it cannot help the Hovenkamps because they disclaim any reliance on a total welfare standard. ${ }^{56}$ Moreover, neither of the two sources - Posner and Tirole - that the Hovenkamps cite for the claim that tying is like second-degree price discrimination supports their total welfare claim. ${ }^{57}$ Posner states that second-degree price discrimination probably worsens total welfare. ${ }^{58}$ Tirole's specific model leads to a conclusion that tying cannot increase total welfare without increasing tying product output, which is the opposite of what the Hovenkamps attempt to deny with their analogy. ${ }^{59}$ More recently, Elhauge and

\footnotetext{
${ }^{50}$ Hovenkamp \& Hovenkamp, supra note , at 935-36; Lambert, supra note , at 937-41.

${ }^{51}$ Hovenkamp \& Hovenkamp, supra note , at 928-29, 934.

${ }^{52}$ Id. at $929,934$.

${ }^{53}$ Id. at 928, 937-38. See also Lambert, supra note, at 938 (echoing this analogical claim).
}

54 See Frederic M. SCHERER \& DAVID Ross, INDUSTRIAL MARKET STRUCTURE AND ECONOMIC PERFORMANCE 494 (3d ed. 1990) (all price discrimination redistributes consumer surplus to producers); MASSIMO MotTA, COMPETITION POLICY 495 (2004) (second-degree price discrimination has effects similar to perfect price discrimination and can "appropriate all consumer surplus"); Hovenkamp \& Hovenkamp, supra note , at 928 \& n.17 (offering the preceding cites in favor of the contrary proposition that second-degree price discrimination generally increases consumer welfare). Other sources likewise indicate that second-degree price discrimination typically reduces consumer welfare. DON E. WALDMAN \& EliZABETH J. JENSEN, Industrial OrGANIZATION 393 (1998); see also CARlton \& Perloff, Modern Industrial Organization 92 (3d ed. 1999) (suggesting the same through example). Lambert cites no literature to support his claim that "second-degree price discrimination . . typically enhances consumer welfare." Lambert, supra note , at 935.

55 Herbert Hovenkamp, Federal Antitrust Policy 576 ( $3^{\text {rd }}$ ed. 2005) ("All forms of persistent price discrimination transfer wealth away from consumers and towards sellers.").

${ }^{56}$ Hovenkamp \& Hovenkamp, supra note, at 927, 929. See also Edlin, Hemphill, Hovenkamp \& Shapiro, Activating Actavis, ANTITRUST (2013) (noting that recent Actavis decision was "unanimous in adopting the consumer welfare approach.”).

${ }^{57}$ Id. at 936 n. 60 .

${ }^{58}$ Richard A. Posner, Vertical Restraints and Antitrust Policy, 72 U. Chi. L. Rev. 229, 236 (2005) (stating that "in the case of second-degree price discrimination, ... the net effect on economic welfare is probably negative.")

59 JeAn TiRole, The TheOry OF Industrial ORganizATION 147-48 (1988) (proving that an "important difference" between ties and pure second-degree price discrimination is that (like third-degree price discrimination) 
Nalebuff have provided a general proof that (like third-degree price discrimination) neither metering ties and second-degree price discrimination can increase total welfare (or consumer welfare) without increasing tying product output. ${ }^{60}$

Nor are the Hovenkamps and Lambert correct in their underlying rationale that because metering ties use the same price schedule for all buyers "the distortion . . . is the same for everyone" and "all consumers receive the same valuation", which is what drives their conclusion that such ties cannot reallocate output from high-value to low-value buyers and "need not increase total output in order to enhance welfare." acknowledge, buyers vary not only in their usage of the tying product, but also in how much they value each usage. ${ }^{62}$ Therefore, each buyer's valuation of the tying product turns on a combination of their per-usage value and their usage rate. Without a tie, the seller sets a separate price for the tying product, which will then be sold to all buyers who find that price lower than the total value they get from the tying product, given both their per-usage value and their usage rate with the tied product sold at a competitive price. Thus, without a tie, every buyer who gets the tying product values it more highly than the buyers who do not get it, given the combination of their per-usage value and usage rate. With a tie, the seller maximizes profits by lowering the tying product price but raising the tied product price, and thus will instead sell to buyers who get the most value per use out of the tying product, even if they do not use it often. The effect is to reallocate some tying product output from buyers who value the tying product more highly (because they would use it more often) to buyers who value the tying product less highly (because they use it less often even though their value per use is higher).

To illustrate, suppose the following. Each buyer uses a printer $n$ times, where $n$ varies for different buyers between 0 and 2000 times in a normal bell-shaped distribution with a mean usage of 1000 and a standard deviation of 200 (i.e., 20\% of the mean). Buyers value each copy they make by $v$, which varies linearly for different buyers between $\$ 0$ and $\$ 2$. The tying and tied product both cost zero to make, and the firm is a monopolist in the tying product but the tied product market is perfectly competitive. The Appendix proves that, without tying, the profitmaximizing price for the printer would be $.48(1000)(\$ 2)=\$ 960$. The value each

\footnotetext{
a "tie-in sale reduces [total] welfare" unless it expands tying product output by expanding the categories of buyers who would buy) (emphasis in original).

${ }^{60}$ See Elhauge \& Nalebuff, supra note, at

${ }^{61}$ Hovenkamp \& Hovenkamp, supra note , at 937-938 (emphasis in original); Lambert, supra note , at 938 (emphasis added).

${ }^{62}$ Hovenkamp \& Hovenkamp, supra note, at 933.
} 
buyer puts on the printer would be $n$ times $v$, and thus they would buy whenever $n$ times $v$ exceeds $\$ 960$. On the graph below, the curved line indicates where $n$ times $v=\$ 960$. Thus buyers would purchase the printer whenever they are above this curved line, which means that buyers in both areas $X$ and $Y$ would both buy the printer without tying.

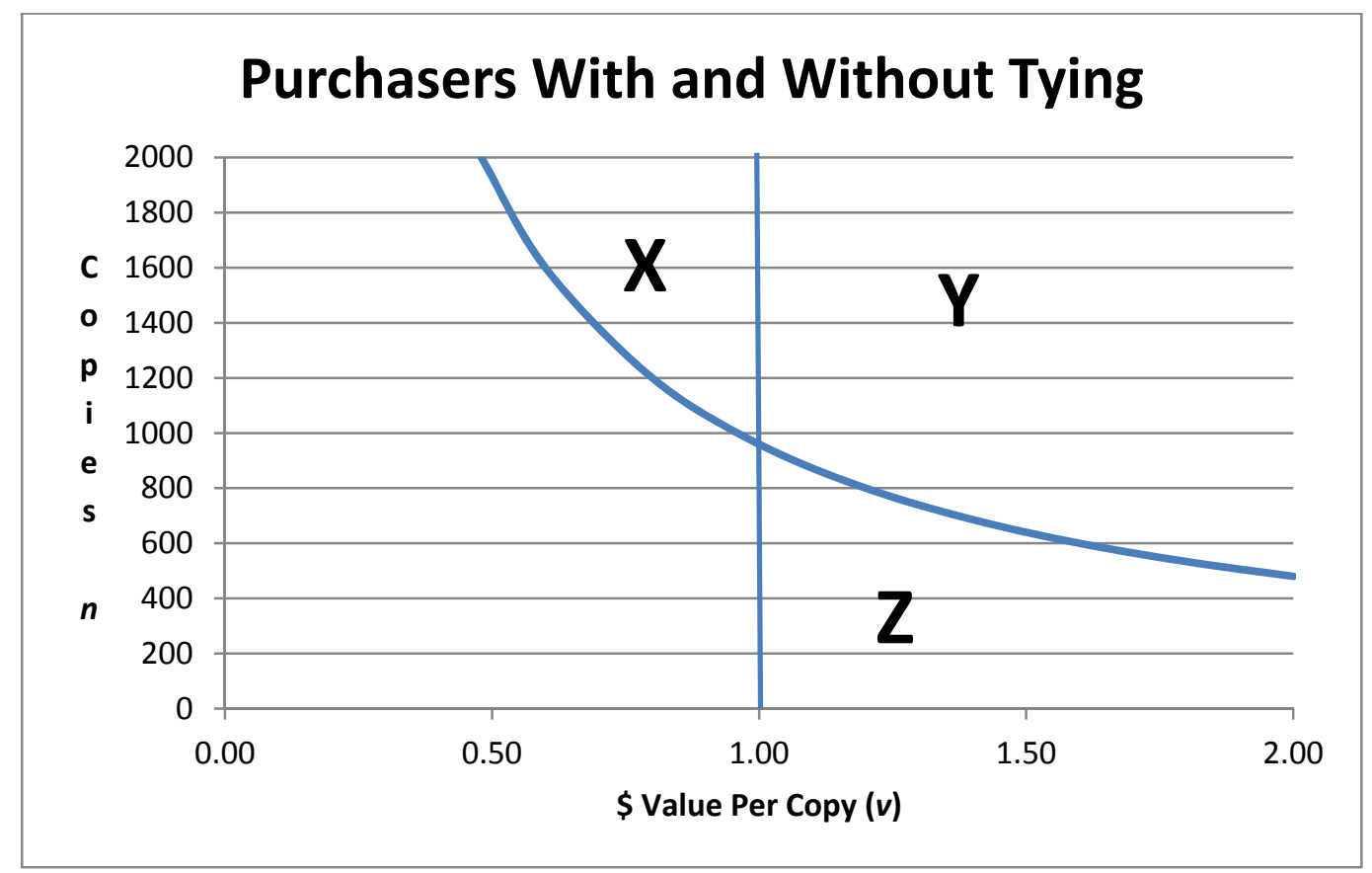

With a tie, the firm would maximize profits by setting the printer price to zero and the consumable price per copy at $\$ 1$. Buyers would buy the printer only if $v>\$ 1$. Thus, buyers in areas $Y$ and $Z$ would purchase the printer. Accordingly, the tie would reallocate printer output from buyers in area $X$ to buyers in area $Z$, even though buyers in area $X$ value the printer more because they would use it more often. Everyone in area $X$ values the printer by more than $\$ 960$, while everyone in area $Z$ values the printer by less than $\$ 960$. Thus, the tie reallocates some printer output from higher-value users to lower-value users, which is an inefficiency. To be sure, the $0.3 \%$ increase in total printer output means that the number of induced buyers in area $\mathrm{Z}$ must exceed the number of excluded buyers in area $X$, which is an offsetting efficiency. But the reallocation of printer output to lower-value buyers remains an inefficiency that must be taken into account. As the Appendix proves, the net effect is that total welfare declines by $1.3 \%$ and consumer welfare declines by $11 \%$. 
The Hovenkamps also offer their own formal model, upon whose conclusions Lambert relies. ${ }^{63}$ However, this model is flawed in various ways that bias their analysis, and in any event its conclusions fail to support their claims about likely welfare effects.

First, the Hovenkamps' assume that different types of buyers vary only in a unidimensional "intensity level" that simultaneously determines both "how many units of [the tied product] the consumer demands" and "the height of his marginal utility curve or, more accurately, its y-intercept." $" 64$ In other words, their model assumes a perfect correlation between $n$ and the maximum $v$ for each buyer. This first assumption directly conflicts with their own concession elsewhere that buyers' tying product usage rates may differ from their per-use valuation. ${ }^{65}$ To use their example, a law firm drafting legal opinions might print the same number of pages as a printer of garage sale handbills even though "the law firm might value printing at many dollars per page, while the handbill printer values printed pages at only a few cents. $" 66$ Unfortunately, their model precludes their own example because it assumes that the fact that the law firm prints the same number of pages as the handbill printer must mean that they value those pages the same. In contrast, the models by Elhauge-Nalebuff and in my Appendix assume that buyers can vary on two dimensions: their usage rate and their value per usage.

The Hovenkamps' first assumption has the effect of biasing their analysis because assuming a perfect correlation assumes away the imperfect correlations that are what create the adverse welfare effects. More specifically, this assumption leads them to the incorrect conclusion that there are no buyers who are ever priced out of the tying product market by a tie that raises the tied price to supracompetitive levels. Instead they conclude that there are only three types of consumers: (1) low intensity consumers who buy the tying product because of the tying product discount; (2) medium intensity consumers who buy the tying product either way and for whom the tying product discount exceeds the inflated amount they pay for the tied product; and (3) high-intensity consumers who buy the tying product either way but for whom the tied product inflation exceeds the tying product discount. ${ }^{67}$ Relying on the Hovenkamps, Lambert likewise assumes those are the only three types of consumers. ${ }^{68}$ In other words, they have assumed away all the buyers in

\footnotetext{
${ }^{63}$ Id. at 944-52, 968-76; Lambert, supra note , at 939-40.

${ }^{64}$ Id. at $968-69$.

${ }^{65} \mathrm{Id}$. at 933.

${ }^{66} \mathrm{Id}$.

${ }^{67}$ Id. at 944, 949, 972.

${ }^{68}$ Lambert, supra note, at 939.
} 
area $X$ in the above graph. A proper, balanced model would have to take into account that in addition to those three groups there is another: (4) buyers driven out of the market by the tied product premium. For this group, those in area $X$, there is a loss in both consumer welfare and total welfare. Not surprisingly, a model that ignores group 4 slants the analysis in favor of finding a welfare increase.

Second, the Hovenkamps' model assumes a random set of possible tying terms, without ever considering whether those terms are profit maximizing or even more profitable than a separate sale. ${ }^{69}$ In contrast, the models by Elhauge-Nalebuff and in my Appendix expressly address whether the tie is profitable and derive the profit-maximizing terms before assessing what effects the tie will have on consumer welfare and total welfare. The Hovenkamps' failure to model the profitability of ties slants their analysis because (as they themselves concede) a "tie is profitable and thus will be imposed, if the gains from the first and third group exceed the losses from the intermediate group."70 This means that a profitmaximizing firm that ties will set prices in a way that minimizes the size of unprofitable group 2 relative to profitable groups 1 and $3 .^{71}$ This in turn undermines the assumption of the Hovenkamps and Lambert that group 2 is just as likely to be large as groups 1 and $3 .^{72}$

Moreover, even if you accept the Hovenkamps' model, they derive only two conclusions from it. First, they conclude that their model proves a tie harms consumer welfare unless the tie expands tying product output by selling tying products to some low-intensity customers in group 1 who would not have purchased them without tying. ${ }^{73}$ But this is precisely the proposition that they and Lambert denied when they argued that tying was more analogous to second-degree price discrimination than to third-degree price discrimination. Thus, their own model disproves their argument from analogy, and instead it supports the point that a tie cannot enhance welfare unless it increases tying product output.

Second, they conclude that if a tie does expand tying product output by inducing purchases from group 1, then "the welfare effects of the tie are not obvious,

${ }^{69}$ Id._at $969-975$.

${ }^{70} \mathrm{Id}$. at 944 . Actually, their assumption that the tie will be profitable for the third high-intensity group rests on their first mistaken assumption that none of them are priced out of the tying market. If one takes into account the fact that some high-usage buyers will be priced out of the market, then the lost profits from failing to sell to such buyers might exceed the profit gain from the fact that other high-usage buyers will continue to buy the tying product and pay more for the tied product.

${ }^{71}$ The size of the groups will be altered by pricing because the Hovenkamps define the groups not according to fixed buyer preferences, but rather by whether or not they benefit from tying given the prices they are charged.

${ }^{72}$ Id. at 949-50, 952; Lambert, supra note, at 939-40.

${ }^{73}$ Hovenkamp \& Hovenkamp, supra note , at 944-45, 973. 
because some consumers are better off, while others are harmed." $" 74$ They then find that the consumer welfare effects are "ambiguous" if we do not know the distribution of consumers because one can imagine distributions that would increase or decrease consumer welfare. ${ }^{75}$ It is true that if one assumes a distribution that is sufficiently slanted towards low-usage rate buyers, one could find a tie that might increase consumer welfare. However, that does not alter the fact that the consumer welfare effects are clearly negative if one makes any neutral assumption about the distribution of customers - such as either the normal bellshaped distribution I assume in the Appendix or the uniform or lognormal distributions assumed by Elhauge and Nalebuff. Conclusions from such a neutral assumption are clearly more relevant to assessing the likely effects of ties, and are not at all disproven by the fact that one can assume slanted distributions that might make some ties welfare enhancing.

Even if you do accept the two conclusions of the Hovenkamps' model, it adds up to the proposition that there are two sets of cases: (a) one set where ties clearly harm consumer welfare; and (b) and another set where ties have ambiguous consumer welfare effects. Those conclusions can hardly justify the Hovenkamps' overall welfare claim that ties almost always enhance consumer welfare, let alone their ultimate policy claim to have justified a rule of per se legality for ties without a substantial tied foreclosure share. Instead, those propositions would support the quasi per se branch of tying doctrine that applies a rule of reason to such ties, rather than per se legality.

\section{Profit Dissipation Makes It Even More Likely That Ties Decrease Total Welfare}

For all three types of ties without a substantial foreclosure share that I analyzed above, the above conclusions about the likely total welfare effects of ties assumed away any profit dissipation, reporting instead only the immediate effects after such ties if we assume zero implementation costs, zero agency costs, and zero ex ante costs. In reality, all three of those costs are likely to dissipate some or all of the profit increase, thus making it even more likely that these ties will reduce total welfare. First, implementing ties is actually costly. It requires sellers to incur expenditures to monitor compliance or design products to prevent noncompliance, and it often causes buyers to spend resources to avoid ties or to suffer the costs of

\footnotetext{
${ }^{74}$ Id. at 973.

${ }^{75} \mathrm{Id}$. at 974-75.
} 
inferior technologies designed to prevent such avoidance strategies. ${ }^{76}$ These implementation costs will dissipate some of the increased profits and increase the consumer welfare harm. Second, firms tend to dissipate some share of supracompetitive profits through greater managerial inefficiency, called Xinefficiency. $^{77}$ Because corporate law theory predicts that product market competition normally constrains agency costs, higher supracompetitive profits will lower that constraint, thus increasing agency costs and X-inefficiency. ${ }^{78}$ Third, even without any implementation or agency costs, firms will incur ex ante costs in the competition to gain the position of market power that are likely to dissipate supracompetitive profits, as Judge Posner first pointed out. ${ }^{79}$ Indeed, Judge Posner predicted that this ex ante dissipation will be $100 \%$ because firms will incur costs to compete for a position of market power until those ex ante costs equal their expected supracompetitive profits from winning that competition. ${ }^{80}$ If so, then all the additional monopoly profits produced by tying will be dissipated ex ante, so that the full total welfare effects actually equal the consumer welfare effects, which the models above show are negative.

Professor Franklin Fisher has disputed that this ex ante dissipation will be the full $100 \%$, because sometimes firms luck into unearned market power or because there might be rising marginal costs to obtaining market power. ${ }^{81}$ These points are debatable: lucking into market power seems rare and requires no reward to incentivize, and Posner's assumption is consistent with the usual economic assumption that long run costs are constant. But even if Fisher is correct, it still means there is some significant ex ante dissipation, just not the full $100 \%$. The

76 See Warren S. Grimes \& Lawrence A. Sullivan, Illinois Tool Works, Inc. v. Independent Ink, Inc.: Requirements Tie-Ins and Intellectual Property, 13 SW. J.L. \& TRADE AM. 335, 350-51 (2007); Nalebuff, supra note , at 232 .

77 See Harvey Leibenstein, Allocative Efficiency vs. X-Efficiency, 56 AM. ECON. REV. 392 (1966); Harvey Leibenstein, X-Inefficiency Xists--Reply to an Xorcist, 68 AM. ECON. REV. 203, 211 (1978); Harvey Leibenstein, On the Basic Proposition of X-Efficiency Theory, 68 AM. ECON. REV. 328 (1978). See generally Elhauge, Defining Better Monopolization Standards, 56 STANFORD LAW REVIEW 253, 299-300 (2003).

${ }^{78}$ See Elhauge, Defining Better Monopolization Standards, supra note _, at 299-300; Mark J. Roe, Rents and Their Corporate Consequences, 53 STAN. L. REV. 1463, 1472-73 (2001); Harold Demsetz, The Structure of Ownership and the Theory of the Firm, 26 J.L. \& ECON. 375, 379 (1983); Daniel R. Fischel, The Corporate Governance Movement, 35 VAND. L. REV. 1259, 1264 (1982).

${ }^{79}$ See Richard A. Posner, The Social Costs of Monopoly and Regulation, 83 J. POL. ECON. 807, 807-09, 822 (1975); Elhauge, Tying, supra note, at 438, 441-442.

${ }^{80}$ Because much of those ex ante costs are incurred by firms that ultimately lose the competition to gain the position of market power, the firm that wins that position will enjoy profits in excess of its own ex ante costs. Comparing the profits of firms that win positions of market power to their own ex ante costs thus provides a misleading indication of the total welfare effects. For total welfare, what matters is that the sum of ex ante costs for all firms equals the expected supracompetitive profits from gaining that position.

${ }^{81}$ See Franklin M. Fisher, The Social Costs of Monopoly and Regulation: Posner Reconsidered, 93 J. POL. ECON. 410 (1985); Elhauge, Tying, supra note, at 441-442. 
other two factors will also each result in some profit dissipation, although each of them will be less than $100 \%$. Implementation costs cannot dissipate $100 \%$ of the additional profits from tying because, if they did, they would eliminate any incentive for the firm to tie at all. Increased X-inefficiency cannot dissipate $100 \%$ of profits because it is a feedback effect that depends on the existence of some additional profit that increases agency costs. ${ }^{82}$ Thus, even if Fisher is correct, some significant profit dissipation will likely be caused by each of these effects - and certainly by all three in combination.

Moreover, because the total welfare gain is often small in relation to the consumer welfare harm, it may take only a small percentage dissipation of the increased profits in order to make the tie harmful to overall total welfare. For example, take the case of a metering tie where the rates at which consumers use the tying product are normally distributed. Then, the minimum necessary dissipation rate is $0 \%$ for bell curves whose standard deviation is up to $40 \%$ of the mean because in those cases ties harm total welfare even without any dissipation. ${ }^{83}$ Moreover, the minimum necessary dissipation rate is only $1.2 \%$ to $4.9 \%$ even for flatter bell curves where the standard deviation is $50-100 \%$ of the mean.

The results are striking. Any one of the three sources of profit dissipationimplementation costs, increased agency costs, and ex ante costs - seem likely to dissipate at least $5 \%$ of the increased profits from a tie. The implementation costs of enforcing contractual ties or designing a product so rival tied products cannot work with it are often high, as are the customer costs of trying to avoid such ties. $\mathrm{X}$-inefficiency alone has been measured as averaging from $10-18 \%$ of costs, $10 \%$ of total welfare, and as much as $81 \%$ of profits. ${ }^{84}$ Ex ante dissipation may be reduced by luck and rising marginal costs, but those two factors would have to eliminate more than $95 \%$ of ex ante costs to reduce profit dissipation to below $5 \%$, which seems implausible. The three sources in combination are even more likely to exceed $5 \%$ of profits. If so, then metering ties harm total welfare for any bell curve with a standard deviation from $10 \%$ to $100 \%$ of the mean.

${ }^{82}$ Elhauge, Defining Better Monopolization Standards, supra note _, at 300.

${ }^{83}$ See [cross-reference].

${ }^{84}$ Kenneth J. Button and Thomas G. Weyman-Jones, Ownership Structure, Institutional Organization and Measured X-Efficiency, 82 Amer. Econ. Rev. 439, 444 (1992) (18\% of costs); Roger Frantz, X-Efficiency and Allocative Efficiency: What Have We Learned?, 82 Amer. Econ. Rev. 434 (1992) (10\% of total welfare); Walter J. Primeaux, Jr., An Assessment of X-Efficiency Gained Through Competition, 59 Rev. Econ. \& Stat. 105, 105-07 (1977) (10.75\% of costs); John P. Shelton, Allocative Efficiency vs. "X-Efficiency": Comment, 57 AM. ECON. REv. 1252,1257 (1967) ( $81 \%$ of profits). 
The only tying-law critics to address profit dissipation have been the Hovenkamps, who mistakenly assert that the point that ex ante costs can dissipate profits "confuses increased expected profits to the innovator with the extraction of increased consumer surplus" and thus ignores the possibility that conduct might increase profits without decreasing consumer surplus. ${ }^{85}$ They are mistaken because the possibility that profit dissipation changes the total welfare conclusion arises only when tests based on total welfare and consumer welfare diverge, which necessarily means that the tie increases profits while decreasing consumer welfare. ${ }^{86}$ Further, their claim that ties usually increase profits without decreasing consumer welfare rests on their premise that ties "increase tying and tied product output" and increase revenue on the tied product without reducing its output. ${ }^{87}$ However, as noted above, the economic literature conflicts with their claim that ties generally increase consumer welfare, and their premise here that ties increase output of the tied product conflicts not only with that literature, but also with their own finding elsewhere in their article that ties can reduce tied product output. ${ }^{88}$

The welfare effects can be even more likely to be negative if we take into account the fact that ties often exploit a lack of buyer information regarding their likely future purchases. ${ }^{89}$ To be conservative, my analysis assumes the absence of any buyer information problem, but to the extent such a problem did exist, it would only increase the odds that ties without a substantial foreclosure share could harm both consumer welfare and total welfare.

\section{E. Implications for Appropriate Legal Standards}

How the Quasi Per Se Rule Fits the Three Extraction and Price Discrimination Effects. The economics summarized above shows that ties without a substantial foreclosure share can lower consumer welfare and total welfare in three possible ways. All three ways require market power in the tying product, so it makes sense to require tying market power to prove these effects. For all three ways, the degree of effect on welfare depends on the dollar amount covered, so to screen out trivial harms, it makes sense to require a nontrivial dollar amount of sales of the tied product. But none depend on a substantial foreclosure share. The quasi per se rule thus correctly tracks these economics by requiring tying market power and a

\footnotetext{
${ }^{85}$ Hovenkamp \& Hovenkamp, supra note , at 953.

${ }^{86}$ Elhauge, Tying, supra note , at 438-442.

${ }^{87}$ Hovenkamp \& Hovenkamp, supra note , at 953-954.

${ }^{88}$ Id. at 930.

${ }^{89}$ See Oren BAR-GiLl, SEduCtion By CONTRACt (2012); Grimes \& Sullivan, supra, note, at 342-43, 349.
} 
nontrivial dollar amount of foreclosure, and by not requiring a substantial foreclosure share.

The existence of these possible adverse welfare effects does not mean there cannot be offsetting procompetitive justifications. Ties can have procompetitive justifications, including not only justifications unrelated to the above theories but also proof that in the particular case the tie does increase consumer welfare or total welfare. So the economics does not support a categorical conclusion that ties with market power always reduce consumer welfare and total welfare. However, the existence of these possible adverse effects also means that the economics disproves any categorical conclusion that ties without a substantial foreclosure share never reduce consumer welfare and total welfare. Tying law correctly tracks these economics by judging ties with tying market power under a rule of reason that permits the introduction of procompetitive justifications, thus rejecting both per se illegality and per se legality.

The above summary holds whether one believes the correct legal standard is consumer welfare or total welfare. In particular, because the economics shows that ties without a substantial foreclosure share can sometimes reduce total welfare, the economics would not support per se legality for such ties even if we changed to a total welfare standard.

The Quasi-Per Se Rule's Presumption. Another issue is whether the choice between consumer welfare and total welfare affects the appropriate presumption to use when applying this rule of reason. If one correctly uses the consumer welfare standard embraced by antitrust law, the appropriate presumption is a slam dunk because the economics clearly shows that unjustified ties with tying market power generally reduce consumer welfare under any neutral assumption about the distribution of buyer preferences. This is true under all three effects. The above conclusions might not hold if one can show strong efficiencies or unusual demand, but the economics clearly supports a presumption that ties with tying market power harm consumer welfare. Again, the economics fit current tying law, which presumptively condemns ties with market power, putting the burden on the defendant of proving an offsetting procompetitive justification.

Even if antitrust law were changed to adopt a total welfare standard, a presumption of illegality would still be warranted for ties with tying market power. When the tie does not involve a fixed ratio and buyers purchase multiple units of the tying product, then such ties cause intra-consumer surplus extraction that harms total welfare in the typical tying case where the buyers subject to the tie value the tying 
product significantly more than the tied product. When the tie bundles two products that have separate utility and for which market power exists, then the tie creates inter-product price discrimination that usually harms total welfare. When a tie creates intra-product price discrimination, it also usually harms total welfare with a normal distribution unless the desired usage of the tied product is very dispersed, especially if one considers the likely dissipation of profits from implementation costs, agency costs, and ex ante costs. Thus, the economics indicates that ties with market power generally reduce total welfare as well.

Moreover, where to put the presumption does not turn only on whether most ties seem likely to violate the relevant welfare standard. It also depends on who is likely to have better access to information on the topic. Because defendants have greater access to information about the welfare effects of their ties, an additional benefit of allocating the presumption against them is that it induces them to produce that information, so that the tribunal can assess it.

In any event, the economic literature indicates that the Supreme Court made what was at least a reasonable policy choice when it concluded that ties without a substantial foreclosure share are, when tying market power exists, likely enough to harm consumer welfare to merit antitrust condemnation absent proof of an offsetting procompetitive justification. The critics have offered no persuasive proof that this policy choice was so unreasonable that the standard presumption of adhering to stare decisis has been rebutted.

The Alternative of Direct Price Discrimination. Some critics argue that, because direct forms of price discrimination are often legal, the Court is wrong to condemn tying agreements that facilitate price discrimination. ${ }^{90}$ However, direct price discrimination (unlike tying) does not impose a restraint on trade because it does not impose conditions that restrict market choices and thus is not covered by Sherman Act $\S 1$. Moreover, direct price discrimination is sometimes illegal under the Robinson Patman Act, and even when it is not, the Supreme Court seems correct that tying agreements will often enable firms to achieve more price discrimination they could have achieved directly. ${ }^{91}$ Indeed, because tying agreements lead to suboptimal purchases of the tied product and require incurring implementation costs, it is hard to see why firms would ever incur those inefficiency costs unless the tie permitted greater price discrimination than could be achieved directly.

\footnotetext{
${ }^{90}$ Elhauge, Tying, supra note, at 427-30 (collecting sources).

${ }^{91}$ Id. at 427-28; Economides, supra note, at 124.
} 
The fact that antitrust law declines to prohibit certain forms of direct price discrimination does not mean that those forms are desirable, just like the fact that the law declines to prohibit oligopolistic price coordination does not mean that that such coordination is desirable. In both situations, the declination merely means that the law cannot define an administrable violation given the fact that setting a price is, unlike tying, an unavoidable market activity. ${ }^{92}$ Indeed, one reason we may be reluctant to prohibit all price discrimination is that simple price discrimination can undermine oligopolistic price coordination. But even though the law does not prohibit oligopolistic price coordination, the law does prohibit agreements that facilitate it. ${ }^{93}$ Likewise, it makes sense that even when the law does not prohibit direct price discrimination, it does prohibit agreements that facilitate it. In both situations, the fact that the law declines to prohibit undesirable unilateral pricing for sound administrative reasons does not prevent the law from prohibiting agreements that make things worse.

The Exception for Fixed Ratio Ties of Products that Lack Separate Utility. The underlying economics allows us to define a limited category of cases where ties without a substantial foreclosure share cannot have anticompetitive effects even with tying market power. If the tie involves products sold or used in a fixed ratio, then the tie cannot cause intra-consumer surplus extraction or intra-product price discrimination because those effects depend on variations in that ratio. A fixedratio tie can still cause inter-product price discrimination. But inter-product price discrimination depends on a lack of strong positive demand correlation that will not hold if the products lack any separate utility. Thus, if the tie involves products that both have a fixed ratio and lack separate utility, then the tie cannot have any of the three anticompetitive effects that ties with tying market power can produce without a substantial foreclosure share. Thus, the quasi-per se rule should not apply to ties that involve products in a fixed ratio that lack separate utility.

As shown below, this exception fits an oft-neglected portion of Jefferson Parish which observed that the tie there of hospital services to anesthesiology involved a fixed ratio tie of products that lacked separate utility that meant the tie could not create price discrimination effects, which the court reasoned meant it did not involve the sort of market power that should trigger the quasi per se rule. ${ }^{94}$ This exception also fits the reasoning of the Kodak dissenters that the quasi per se rule should not apply because they believed the tie there of service to machine parts

\footnotetext{
${ }^{92}$ Elhauge, Tying, supra note, at 428.

${ }^{93}$ Elhauge, U.S. Antitrust, supra note , at 562-84.

${ }^{94}$ See infra Part III.A.
} 
involved a fixed ratio tie of products that lacked separate utility and thus could not achieve extraction or price discrimination effects, and the fact that the Kodak majority rejected this reasoning only because the majority disagreed with those factual premises given that parts and service were often purchased without the other. ${ }^{95}$ Finally, this exception fits the facts of the famous D.C. Circuit decision in United States v. Microsoft Corp., which held that, despite tying market power, the quasi-per se rule did not apply to a tie of operating systems and browsers. ${ }^{96}$ Although the court's reasoning for doing so was obscure and did not expressly rely on the facts that the products were bundled in a fixed ratio and the browser lacked separate utility, those facts did mean that anticompetitive effects required proving a substantial foreclosure share, as the court required. ${ }^{97}$

\section{The Critics’ OWn Policy Analysis Does Not Justify Their Doctrinal Positions}

Even if one accepted the critics' mistaken claim that ties with tying market power usually have positive effects on consumer welfare and total welfare, their analysis would not support their position that ties without a substantial foreclosure share should be per se legal. After all, the critics of current tying law themselves admit that ties without a substantial foreclosure share sometimes harm both consumer welfare and total welfare when tying market power exists. ${ }^{98}$ Thus, even if one mistakenly accepted their conclusions about likely welfare effects, it would at worst show that most ties without a substantial foreclosure share do not have harmful welfare effects. That conclusion does not at all justify their proposal that courts should make all ties without a substantial foreclosure share per se legal.

Instead, what their conclusion would justify is a rule of reason approach. But that is precisely what the current quasi per se rule provides: requiring evidence of tying market power to prove that anticompetitive effects on consumer welfare are possible, but allowing defendants to prove procompetitive justifications that would indicate that the tie in question produced a net increase in consumer welfare.

Lambert and the Hovenkamps conclude otherwise because they mistakenly equate tying law's quasi per se rule with a rule of per se illegality that condemns ties with

${ }^{95}$ See infra Part III.C.

${ }^{96} 253$ F.3d 34 (D.C. Cir. 2001).

${ }^{97}$ Elhauge, Tying, supra note, at 402, 446-47.

${ }^{98}$ Carlton \& Heyer, supra note, at 292-93; Crane, supra note, at 28, 32; Hovenkamp \& Hovenkamp, supra note , at 927, 930, 944, 952, 958; Lambert, supra note , at 920, 939; Seabright, supra note , at 244-45; Semararo, supra note, at 37. 
market power even if the defendant can show a procompetitive justification that results in a net benefit to consumer welfare. ${ }^{99}$ However this assertion conflicts with Herbert Hovenkamp's own conclusion in his treatise, where he correctly concludes that:

the Supreme Court permits justifications for ties challenged under the per se rule ... Notwithstanding its development of a 'per se' rule against tying, the Supreme Court has almost always been willing to consider a defendant's offered justifications.... Today, any justification for tying that is theoretically sound can be considered under Supreme Court precedent." 100

As the Hovenkamp treatise reasons, the fact that in some cases the Supreme Court found that the offered justifications were "insufficiently proved in fact" does not at all alter their admissibility whenever justifications can be proven. ${ }^{101}$ Indeed, his treatise shows that in one case applying the quasi per se rule, the Court expressly allowed a cost-justified tie when limiting the remedy, and in two other cases the Court affirmatively held that the trial court on remand should not condemn the tie if offsetting justifications were proven. ${ }^{102}$ Other scholars have similarly concluded that justifications are admissible under the quasi per se rule, and this conclusion is bolstered by clear language in its most recent tying case where the Court emphasized that it had long rejected the view that ties rarely have procompetitive justifications. $^{103}$

Thus, procompetitive justifications are and should be admissible under the current quasi per se rule on tying. However, the mere possibility that tying can have such justifications does not support per se legality for ties without a substantial foreclosure share, which would immunize defendants who have no evidence that their ties have procompetitive justifications. Instead, that possibility supports

\footnotetext{
${ }^{99}$ Lambert, supra note, at 959-962; Hovenkamp \& Hovenkamp, supra note , at 958, 960, 965-66 (equating the current quasi per se rule that I defend with a rule that excludes justifications).

${ }^{100}$ X Phillip E. AREEDA \& Herbert HovenKAMP, ANTITRUST LAW 372-73 (3rd ed. 2011); see also id. at 376382 (showing that five Supreme Court cases have recognized the admissibility of justifications under the quasi per se rule).

${ }^{101}$ Id. at $371,378,381$.

${ }^{102}$ Id. at $371,378,381$.

${ }^{103}$ Illinois Tool Works, 547 U.S. at 36, 46; Elhauge, Tying, supra note, at 400, 425-26. Lambert argues that this rejection is somehow undermined by its long-standing nature. Lambert, supra note, at 960-61. However, the Illinois Tool Works conclusion that the Court had long rejected this view merely confirms the Hovenkamp treatise analysis that the Court has long been willing to consider procompetitive justifications, even though in many cases the court found those justifications unproven. Lambert also argues that unless procompetitive justifications are excluded, he cannot fathom the Jefferson Parish distinction between the two branches of the bifurcated rule of reason, id. at 961, but the distinction is simply between two possible ways of proving anticompetitive effects, both of which are subject to rebuttal by offsetting procompetitive justifications.
} 
considering such justifications in cases when they have actually been proven and shown to offset any anticompetitive effects.

Some critics argue, based on casual observation, that most product bundles that they see without a substantial foreclosure share appear to benefit consumer welfare and that this means they should be per se legal. ${ }^{104}$ However, even if we assume the accuracy of their observation, this method deviates from standard antitrust analysis. As the Supreme Court has long emphasized, every contract restrains trade, and surely most contracts are desirable, but this does not mean that we treat all contracts as per se legal. Instead, the accepted approach is to make all restraints subject to at least a rule of reason to sort out the restraints that benefit consumer welfare from those that harm it. ${ }^{105}$ Even if most product bundles are desirable, that is irrelevant because tying doctrine only condemns bundles of (1) separate products (2) with tying market power (3) that lack offsetting procompetitive justifications. What critics cite as desirable bundles are missing one or more of these elements, and thus would not be condemned by current tying doctrine. ${ }^{106}$ Critiquing current tying doctrine based on an empirical claim that most bundles are desirable is like condemning laws against drunk driving based on an empirical claim that most driving is desirable. Instead, a proper empirical critique would require a showing that the subset of ties that are actually condemned by current doctrine usually benefit consumer welfare. No one has offered any such empirical evidence.

Defending current doctrine requires no sweeping empirical premise because its bifurcated rule of reason provides a case-by-case empirical assessment of whether welfare-increasing effects actually exist. ${ }^{107}$ To whatever extent the critics are empirically right that ties enhance consumer welfare, current doctrine would not prohibit those ties. In contrast, the critics' argument for per se legality for ties with market power that lack a substantial foreclosure share would require strong empirical evidence that such ties virtually never harm consumer welfare. The critics never provide any such empirical evidence.

104 Daniel A. Crane \& Joshua D. Wright, Can Bundled Discounting Increase Consumer Prices Without Excluding Rivals?, 5(2) COMPETITION POL'Y INT'L 209, 210 (Autumn 2009); Lambert, supra note , at 940-41, 95253; Seabright, supra note, at 248-49.

${ }^{105}$ See, e.g., Leegin Creative Leather Products v. PSKS, Inc., 551 U.S. 877, 885-886 (2007).

106 Elhauge, The Failed Resurrection of the Single Monopoly Profit Theory, 6(1) COMPETITION POLICY INT'L 155, 162-63, 174-76 (Spring 2010).

${ }^{107}$ Id. at $159-60$. 


\section{Ties ARE Legally ANTICOMPetitive When They FACILITATE EXTRACTION OR PRICE Discrimination THAT LOWERS CONSUMER WELFARE}

At least one prominent critic of current tying law, Herbert Hovenkamp, acknowledges that if tying agreements did usually or almost always harm consumer welfare, they could be condemned by antitrust law even when they do not impair the general ability of rivals to compete. ${ }^{108}$ He thus disagrees with me on the likely effects, but not on the permissibility of legal condemnation if I am right about the consumer welfare effects. However, other tying-law critics argue vigorously that, even if ties without a substantial foreclosure share do reduce consumer welfare and total welfare because of the extraction and price discrimination effects described in Part I, those effects do not legally count as anticompetitive effects. ${ }^{109}$ Because their claim is that the law would trump any contrary welfare economics, it requires moving beyond pure welfare analysis to a close examination of the actual reasoning and holdings of the case law.

The critics' claim that current law precludes treating the effects of ties as anticompetitive unless a substantial tied foreclosure share exists faces the considerable obstacle that it is the critics who want to change current law. After all, the critics acknowledge that current case law treats ties without a substantial foreclosure share as anticompetitive when tying market power exists; that is precisely what they dislike. ${ }^{110}$ This leaves the critics having to argue that the very Supreme Court precedent that treats ties without a substantial foreclosure share as anticompetitive means that the effects of ties without a substantial foreclosure share cannot be anticompetitive. Critics thus have the considerable burden of proving that, somehow, those precedents legally require overruling their own holdings.

To try to carry that burden, the critics argue that, notwithstanding these holdings, language in these cases shows that the effects of tying are anticompetitive only when they involve the sort of foreclosure share effects that require a substantial tied foreclosure share. ${ }^{11}$ But even if this claim were true (below I show precisely the opposite), it inverts the legal hierarchy of holdings and dicta. Dicta that is unnecessary to a holding is not binding; when dicta actually conflicts with a holding, it clearly lacks any legal force. The foreclosure share effects that critics claim are necessary to show anticompetitive effects are by definition impossible

\footnotetext{
${ }^{108}$ IX Phillip E. AREedA \& Herbert HOVENKAMP, ANTITRUST LAW 107-08, 115 (3rd ed. 2011).

${ }^{109}$ Lambert, supra note, at 909, 913, 927-34; Semararo, , supra note, at 31.

${ }^{110}$ Hovenkamp \& Hovenkamp, supra note , at 967; Lambert, supra note , at 912, 926.

${ }^{111}$ Lambert, supra note, at 913-14, 927-934, 980.
} 
without a substantial foreclosure share, which is just what the precedents hold need not be proven. Moreover, the critics acknowledge that, even under their own analysis, ties without a substantial foreclosure share have the three extraction and price discrimination effects that I describe, that those effects can at least sometimes harm both consumer welfare and total welfare, and at least one of the critics admits that that the Supreme Court cited these sorts of effects when defending the quasi per se rule. ${ }^{112}$ Indeed, the critics agree with me that the quasi per se rule makes no sense unless the price discrimination and extraction theories count as anticompetitive. $^{113}$ Thus, as a matter of actual holding and doctrinal fit, the precedents that condemn ties without a substantial foreclosure share must have deemed these extraction and price discrimination effects to be anticompetitive. This holding trumps any claim that dicta in the precedents suggested the contrary.

Even if we assume that dicta can somehow trump holdings, the critics' interpretation necessarily forces them to argue that the Supreme Court did not know what it was doing when it refused to require a substantial foreclosure share to condemn ties with market power. ${ }^{114}$ Like all of us, the Court surely errs from time to time. But it seems hard to imagine that the Court missed something as obvious as the lack of connection between its holdings condemning ties without a substantial foreclosure share as anticompetitive and the view (attributed by critics to the Court) that ties without a substantial foreclosure share have no anticompetitive effects. At least as a canon of case construction, it seems sensible to interpret case language to be consistent with case holdings, and to have a strong presumption to that effect when the claimed conflict between case language and holdings is so stark.

In any event, the critics are wrong that case language indicates the Supreme Court believed that only foreclosure share effects count as anticompetitive and did not understand what it was doing when it preserved a quasi per se rule that condemned ties without any foreclosure share effects. To the contrary, the case language conclusively supports the opposite interpretation that the Supreme Court preserved the quasi per se rule because it affirmatively believed that extraction and price discrimination effects were also anticompetitive and correctly concluded from the

${ }^{112}$ Hovenkamp \& Hovenkamp, supra note , at 927, 930, 944, 952, 958; Lambert, supra note , at 920, 929, 934, 939; Carlton \& Heyer, supra note, at 292-93.

${ }^{113}$ See Lambert, supra note, at 913-14, 980; Hovenkamp \& Hovenkamp, supra note , at 967.

${ }^{114}$ Lambert, supra note, at 927-28 (claiming "A disconnect between the liability rule the Court adopts and the policy concerns underlying that rule."); Semararo, supra note, at 34 (arguing that the Supreme Court mistakenly "either (1) assumed that price discrimination would restrain competitors in the tied market, or (2) did not seriously consider the possibility that it would not.") 
economic literature that those effects were possible without a substantial foreclosure share. The following details why.

\section{A. The Supreme Court Expressly Distinguished Between Exploiting Market Power By Raising Prices Versus By Using Ties to Expropriate Further Consumer Surplus}

The critics' main argument against treating the price discrimination and extraction effects as anticompetitive is that those effects are indistinguishable from simply raising prices. ${ }^{115}$ Given that premise, they argue that because antitrust case law (including Jefferson Parish) allows firms to exploit their market power by setting a profit-maximizing price, it must also allow firms to expropriate the remaining consumer surplus (that would otherwise exist even at a profit-maximizing price) by using tying agreements that have price discrimination and extraction effects.

The Supreme Court was not unaware of this sort of argument. To the contrary, when the Jefferson Parish Court reaffirmed the quasi per se rule, it explicitly rejected the premise that there was no distinction between exploiting market power by raising prices and by using tying agreements that restrained tied sales in a way that expropriated further consumer surplus. It is remarkable the extent to which this point has been missed, so the key passage is worth covering in some detail. The Court reasoned:

Thus, the law draws a distinction between the exploitation of market power [1] by merely enhancing the price of the tying product, on the one hand, and [2] by attempting to impose restraints on competition in the market for a tied product, on the other. When the seller's power is just used to maximize its return in the tying product market, where presumably its product enjoys some justifiable advantage over its competitors, the competitive ideal of the Sherman Act is not necessarily compromised. But if that power is used to impair competition on the merits in another market, a potentially inferior product may be insulated from competitive pressures. This impairment [3] could either harm existing competitors or create barriers to entry of new competitors in the market for the tied product, and [4] can increase the social costs of market power by facilitating price discrimination, thereby increasing monopoly profits over what they would be absent the tie. ${ }^{23}$ And from the standpoint of the

${ }^{115}$ Carlton \& Heyer, supra note, at 290-92; Crane, supra note, at 32; Lambert, supra note, at 955; Semararo, supra note, at 32-33. 
consumer - whose interests the statute was especially intended to serve - the freedom to select the best bargain in the second market is impaired by his need to purchase the tying product .... ${ }^{116}$

There are several things to note about this passage. First, the Supreme Court expressly drew a distinction between exploiting market power by [1] raising the tying product price, which was permissible, and [2] using a tying agreement that also restrains competition in the tied market, which was not. Thus, the Court directly rejected the critics' premise that these two ways of exploiting tying market power are indistinguishable. Further, the Court said that the reason for the distinction is that restraining competition in the tied market can have both [3] foreclosure share effects and [4] price discrimination effects. Indeed, the Court objected specifically to the fact that tying agreements "can increase the social costs of market power by facilitating price discrimination, thereby increasing monopoly profits over what they would be absent the tie."117 This passage directly refutes the critics' claim that, as long as any market power was lawfully obtained, it is not legally anticompetitive to increase its social costs by restraining trade in a way that facilitates price discrimination. Instead, the Court held that it was anticompetitive to increase monopoly profits over the levels that the defendant could have obtained through simple monopoly pricing without the tie. Finally, the last sentence makes clear that the Court interprets antitrust law to protect consumer welfare (not total welfare) and to be violated if consumers pay higher prices than they would have paid without the tying agreement.

But there's more. The sources that the Supreme Court cited in footnote 23 of the above passage to support the proposition that tying agreements can anticompetitively "increase the social costs of market power by facilitating price discrimination" included all three of the leading articles for each of the three theories for how tying can facilitate price discrimination and consumer surplus extraction, citing to Burstein, Stigler, and Bowman. ${ }^{118}$ Its analysis thus directly indicated that the Court found those three effects to be legally anticompetitive.

Further, to explain why it focused on tying market power rather than on the tied foreclosure share, the Supreme Court explained: "the fundamental restraint against which the tying proscription is meant to guard is the use of power over one product to attain power over another, or otherwise to distort freedom of trade and

\footnotetext{
116466 U.S. at 14-15 (emphasis and bracketed numbers added).

${ }^{117} \mathrm{Id}$.

${ }^{118}$ Id. at 15 n. 23 .
} 
competition in the second product.""119 Because the first clause refers to ties that increase the degree of tied market power, the "otherwise" clause necessarily indicates that the Court concluded that tying could be anticompetitive even when did not increase the degree of tied market power, which is just what the critics are denying. To justify the first clause about how tying could increase tied market power, the Court explained how substantial foreclosure shares could have that sort of anticompetitive effect in the tied market. ${ }^{120}$ To justify the "otherwise" clause, the Court stated:

In addition to these anticompetitive effects in the tied product, tying arrangements may be used to evade price control in the tying product through clandestine transfer of the profit to the tied product; they may be used as a counting device to effect price discrimination; and they may be used to force a full line of products on the customer so as to extract more easily from him a monopoly return on one unique product in the line."

Thus, the Court made perfectly clear that it deemed anticompetitive not only foreclosure share effects, but also price discrimination and extraction effects. Further, the prior opinion that the Court cited for these price discrimination and extraction effects itself relied on the Bowman and Burstein articles. ${ }^{122}$ Moreover, the Court cited all this analysis to explain its conclusion that "competition on the merits in the market for the tied item is restrained" whenever tying market power exists. ${ }^{123}$ Thus, the Court clearly indicated that it viewed the price discrimination and extraction effects as anticompetitive.

${ }^{119}$ Id. at 13 n.19 (emphasis added) (quoting Fortner Enterprises v. U.S. Steel Corp., 394 U.S. 495, 512-14 (1969) (White, J., dissenting).

${ }_{120}$ Jefferson Parish, 466 U.S. at 13 n.19.

${ }^{121}$ Id. (emphasis added) (quoting Fortner, 394 U.S. at 512-14 (White, J., dissenting)).

${ }^{122}$ Fortner, 394 U.S. at 513 nn.7-8 (White, J., dissenting).

123 Jefferson Parish, 466 U.S. at 12-13. Lambert argues that the fact that Supreme Court also included the possibility that tying agreements could evade price controls on the tying product shows that the Court must have viewed all these effects as procompetitive. Lambert, supra note, at 929-30. This argument not only conflicts with all the other evidence that the Supreme Court deemed these effects to be anticompetitive, but also rests on Lambert's mistaken premise that evading price controls is procompetitive. Id. The Supreme Court specifically indicated that its concern was with ties that evaded price controls on the tying product by transferring profits "to" the tied product - i.e., that the concern was with evading price ceilings, not price floors. Thus, Lambert is mistaken in his assertion that evading such price ceilings is "actually output-enhancing and thus pro- not anticompetitive." Id. at 930. As even fellow critic Hovenkamp admits, "Such evasion has the usual consequence of monopoly pricing: elevated prices and depressed output." IX PhILlip E. AREEDA \& HERBERT HOVENKAMP, ANTITRUST LAW 48 (3rd ed. 2011). Further, when assessing whether the particular tie at issue had the sort of tying market power that merited condemnation under the quasi per se rule, the Jefferson Parish Court expressly considered whether the tie was evading any price controls and rejected that argument only because the Court found no factual support for any price control evasion, not because the Court concluded that such evasion would be procompetitive. 466 U.S. at 28 n. 47 . 
The above conclusions are confirmed in a later part of the opinion that unfortunately has generally gone unnoticed. In order to justify its case-specific conclusion that the case at hand did not involve the sort of tying market power that merited condemnation under the quasi per se rule, the Jefferson Parish Court stressed the lack of evidence that the tying agreement at issue had created price discrimination effects. The Court observed that hospital services and anesthesia both lacked any separate utility and were in a fixed ratio, which precluded price discrimination effects:

It is safe to assume that every patient undergoing a surgical operation needs the services of an anesthesiologist... Nor is there an indication in the record that respondents' practices have increased the social costs of its market power. Since patients' anesthesiological needs are fixed by medical judgment, respondent does not argue that the tying arrangement facilitates price discrimination. Where variable-quantity purchasing is unavailable as a means to enable price discrimination, commentators have seen less justification for condemning tying. ${ }^{124}$

The Court thus clearly viewed increasing the social costs of market power by facilitating price discrimination as an anticompetitive effect of tying agreements that justifies their condemnation, and relied on evidence that this anticompetitive effect was not present in the case at hand, rather than reasoning that this effect did not count as anticompetitive.

Moreover, the Court stated that: "When, however, the seller does not have [tying] market power ..., an antitrust violation can be established only by evidence of an unreasonable restraint on competition in the relevant market." 125 Further, because the Court found that such tying market power was absent, it went on to make clear that what it meant by the latter was that the plaintiff would have to prove foreclosure share effects. ${ }^{126}$ The Court's analysis thus made perfectly clear that it believed that a tie with tying market power could have anticompetitive effects without any foreclosure share effects.

\footnotetext{
${ }^{124} 466$ U.S. at 28 \& n. 47.

125466 U.S. at $17-18$.

${ }^{126}$ Id. at 29-31.
} 


\section{B. Why Extraction and Price Discrimination Effects Fit the Legal Requirement to Show the Tie Foreclosed a Substantial Amount of Sales of a Wanted Tied Product}

Thomas Lambert argues that, notwithstanding all the above indications that the Supreme Court viewed price discrimination and extraction effects as anticompetitive, the Court could not have meant what it said because it also limited the quasi-per se rule in two ways that he says are inconsistent with such theories. ${ }^{127}$ This argument has frequently been made in defense briefs for many years, but closer consideration of the relevant antitrust economics shows the argument has it backwards.

The first limit is that Jefferson Parish stated that:

If only a single purchaser were "forced" with respect to the purchase of a tied item, the resultant impact on competition would not be sufficient to warrant the concern of antitrust law. It is for this reason that we have refused to condemn tying arrangements unless a substantial volume of commerce is foreclosed thereby. ${ }^{128}$

Lambert claims that this passage creates a single-purchaser exception that is inconsistent with price discrimination theories and thus shows that the Court thought that only foreclosure share theories counted as anticompetitive. ${ }^{129}$ However, the opposite is true: any single-purchaser exception fits strongly with price discrimination theories but conflicts with foreclosure share theories. After all, a single purchaser could make up a substantial share of the tied market (imagine a buyer who makes up 50\% of the market), and thus a tie that forecloses that single purchaser could produce adverse foreclosure share effects. In contrast, the price discrimination theories by their very nature require discriminating among multiple buyers and thus are not possible unless the tie is applied to multiple buyers. A tie cannot have inter-product and intra-product price discrimination effects unless the tie is applied to multiple buyers whose demand varies.

Accordingly, an exception for any tie involving a single purchaser fits very well with the position that price discrimination effects are anticompetitive, but actually conflicts with the position that foreclosure share effects are anticompetitive. To be sure, such an exception would also conflict with the position that intra-consumer extraction is anticompetitive, because that effect is possible with a single buyer.

\footnotetext{
${ }^{127}$ Lambert, supra note, at 931.

128466 U.S. at 16.

${ }^{129}$ Lambert, supra note, at 931.
} 
But that hardly supports the critics' position that this passage favors foreclosure share theories over price discrimination and extraction theories.

In any event, there is no true inconsistency because Lambert is incorrect that this passage creates an exception for any tie involving a single purchaser. Instead, the second sentence of the passage made clear that the Court was thinking only of a single purchaser who did not buy a substantial volume of commerce, stressing that "it is for this reason [the single purchaser case]" that the Court requires proof that a "substantial volume of commerce is foreclosed." Thus, the Court clearly limited the exception to ties involving a low-volume single purchaser. This makes perfect sense because without a substantial volume of tied sales there can be neither any significant harm to consumer welfare under the price discrimination and extraction theories nor the substantial foreclosure share necessary for the foreclosure share theories. Further, the Court never said, as Lambert claims, that the effects in the case of such a single low-volume purchaser "are not anticompetitive effects." "130 The Court instead said that the "impact on competition would not be sufficient" in magnitude to trigger antitrust condemnation. ${ }^{131}$ Thus, the Court clearly indicated that this exception was based on the small size of the anticompetitive effect, rather than on a conclusion that the nature of this effect was not anticompetitive.

The second limit that Lambert says conflicts with the price discrimination theories is that Jefferson Parish stated that:

Similarly, when a purchaser is "forced" to buy a product he would not have otherwise bought even from another seller in the tied product market, there can be no adverse impact on competition because no portion of the market which would otherwise have been available to other sellers has been foreclosed. ${ }^{132}$

But there is no conflict. Some restraint on competition is a necessary legal trigger for Sherman Act liability, which requires proof of a restraint on trade that harms consumer welfare. If, as in the Court's hypothetical, no restraint on competition exists, then we do not have that necessary legal trigger and thus never reach the question whether the net effects harm consumer welfare.

Moreover, the unwanted-product exception affirmatively fits strongly with the price discrimination and extraction theories as an economic matter. Intra-product price discrimination requires that the consumer wants the tied product to use with the tying product, and thus it cannot occur if the consumer does not want the tied

\footnotetext{
${ }^{130} I d$.

131466 U.S. at 16.

${ }^{132}$ Id.; Lambert, supra note, at 931.
} 
product at all. To put it another way, this theory of consumer harm requires a correlation in product demand that is impossible when there is no demand for one of the products. Inter-product price discrimination requires varying demand for the two products, and thus it too is impossible when consumers have zero demand for the tied product. With zero tied demand, a bundle would amount to simply raising the price on the tying product. Intra-consumer surplus extraction generally involves a requirements tie that requires that the buyer make any tied product purchases from the tying firm at elevated prices. Such a tie cannot extract any surplus if the buyer does not want to buy any of the tied product at all. A firm could also extract intra-consumer surplus with a tie that requires purchasing a fixed amount of a tied product, but it would be irrational to make that tied product an unwanted product because then the tie could not extract any more consumer surplus than replacing the tie with a lump sum fee, and the latter would save the tying firm the costs of making an unwanted product.

In short, the price discrimination and extraction theories require foreclosure of some purchases of a wanted tied product, and thus fit strongly with an exception for ties to an unwanted tied product. The price discrimination theories also require multiple purchasers, and the price discrimination and extraction theories both require foreclosure of a substantial volume of tied sales, so they also fit strong with an exception for ties involving one low-volume purchaser.

Steven Semeraro offers the even more sweeping argument that condemning ties that have extraction or price discrimination effects conflicts with language in Jefferson Parish that requires restraining competition in the tied market. ${ }^{133}$ However, his argument depends on the mistaken premise that condemning ties with market power that lack a substantial tied foreclosure share is the same thing as condemning ties that do not restrain competition at all. ${ }^{134}$ Contrary to his premise, a tying agreement restrains competition for sales of the tied product to buyers subject to the tie, and thus restrains competition on the merits for those sales. Indeed, as Semararo acknowledges, the Supreme Court stressed precisely this when it rejected the argument that it should overrule the quasi-per se rule in Jefferson Parish. ${ }^{135}$ The dispute is not about whether antitrust law should condemn tying agreements even when they do not restrain competition at all. The dispute is over whether critics are correct that we should change antitrust law to condemn tying agreements only when they restrain a substantial share of the tied market. The Court in Jefferson Parish clearly rejected the critics' position, holding

\footnotetext{
${ }^{133}$ Semararo, , supra note, at 34.

134 Semararo, supra note, at 30-32, 34-35, 37.

135466 U.S. at 12-14; Semararo, , supra note, at 34.
} 
that, where tying market power exists, it suffices that the tying agreement restrains competition for substantial dollar amount of sales in the tied market. ${ }^{136}$

The legal grounds for defending the quasi per se rule are quite straightforward given the economic effects. The accepted antitrust standard for assessing whether any restraint on competition is illegal is to ask whether its anticompetitive effects are outweighed by procompetitive effects. ${ }^{137}$ And the metric used to perform this weighing is whether the restraint results in a net decrease or increase in consumer welfare. ${ }^{138}$ Tying agreements are a restraint on competition and thus should be illegal whenever they decrease consumer welfare. When a tie lacks both tying market power and a tied foreclosure share, the restraint cannot harm consumer welfare and thus cannot be the sort of unreasonable restraint of trade that violates the Sherman Act. ${ }^{139}$ However, the critics themselves admit that a tie with tying market power can, even without a substantial foreclosure share, reduce consumer welfare. ${ }^{140}$ There is thus no valid reason to make ties without a substantial foreclosure share per se legal when tying market power exists. Instead, such ties should be illegal whenever they result in a net decrease in consumer welfare. Current law does this with the quasi per se rule, which allows the defendant to prove any procompetitive justification that would result in a net increase in consumer welfare. ${ }^{141}$ Further, even if we changed the antitrust standard to total welfare, the very same analysis would hold because critics acknowledge that ties without a substantial foreclosure share can harm total welfare. ${ }^{142}$

Relatedly, Semararo objects to the observation that: "“[A]ntitrust does condemn conduct that distorts the competitive process in ways that harm consumer welfare even if that conduct does not harm competitors." "143 Here, his argument mistakenly equates this observation with a claim that "antitrust prohibits conduct that does not restrain competition," "144 because in his view ties that restrain the competitive process in a way that harms consumer welfare do not adversely affect "competition" without injury to competitors. ${ }^{145}$ But harm to competition should not be erroneously conflated with harm to competitors. Indeed, equating the two

136466 U.S. at $12-18$.

137 See, e.g., Leegin Creative Leather Products v. PSKS, Inc., 551 U.S. 877, 885 (2007).

${ }^{138}$ See id. at 886 ("the rule distinguishes between restraints with anticompetitive effect that are harmful to the consumer and restraints stimulating competition that are in the consumer's best interest").

139 Jefferson Parish, 466 U.S. at 11-14.

140 See supra Part II.

${ }^{141} \mathrm{Id}$.

${ }^{142} I d$.

${ }^{143}$ Semararo, supra note, at 31\& n.4 (quoting Elhauge, Tying, supra note, at 421-22).

${ }_{144}$ Semararo, supra note, at, 37.

${ }^{145}$ Id. at 35. 
conflicts with the bedrock principle that "the purpose of the antitrust laws . . . is 'the protection of competition, not competitors." "146 The Supreme Court has repeatedly invoked this principle to emphasize that antitrust condemns restraints on competition based on whether they harm "consumer welfare," not whether they injure competitors. ${ }^{147}$ That principle fits quite well with the observation that antitrust condemns restraints on the competitive process whenever they harm consumer welfare, regardless of whether competitors are injured, but fits quite poorly with Semararo's claim that antitrust immunizes such restraints unless competitors are also harmed.

Moreover, ties with tying market power that lack a substantial foreclosure share do harm competitors by depriving them of sales to the tied customers. Such ties do not weaken the ability of competitors to compete for customers who are not subject to the tie, but they do restrain their ability to sell to the tied customers. Thus, even without a substantial foreclosure share, the rivals suffer an antitrust injury that flows from the restraint that makes the tie anticompetitive.

\section{Other Evidence that the Court Understood What It Was Doing and Reaffirmed Jefferson Parish's Economic Logic in Other Cases.}

Notwithstanding the critics' claim that Jefferson Parish did not understand the economic implications of its holding, the Jefferson Parish Court was perfectly aware of the contrary claim that tying could have anticompetitive effects only if it created a substantial foreclosure share. This was not some ancient opinion from an era when the Supreme Court adjudicated antitrust cases based on noneconomic principles of autonomy or was innocently unaware of the Chicago school critique of tying doctrine. This was an opinion issued in 1984, seven years after the Court embraced an economic approach to antitrust and concluded that the economic approach merited paring back on per se rules for vertical agreements and five years after it did the same for horizontal agreements. ${ }^{148}$ The Court was well aware of the Chicago School critique. Indeed, the lawyer representing the defendants in Jefferson Parish was prominent Chicago School scholar Frank Easterbrook, who made the same claim critics make now: that anticompetitive effects were not

${ }^{146}$ Leegin Creative Leather Products v. PSKS, Inc., 551 U.S. 877, 906 (2007) (emphasis in original); Brooke Group Ltd. v. Brown \& Williamson Tobacco Corp., 509 U.S. 209, 224 (1993) (same); see also Copperweld Corp. v. Independence Tube Corp., 467 U.S. 752,768 n.14 (1984) (same without emphasis).

${ }^{147}$ Leegin, 551 U.S. at 906; Brooke Group, 509 U.S at 224; see also Copperweld, 467 U.S. at 768 (using the words "consumer interests" rather than "consumer welfare".)

${ }^{148}$ Continental T.V., Inc. v. GTE Sylvania Inc., 433 U.S. 36 (1977); Broadcast Music, Inc. v. Columbia Broadcasting System, Inc., 441 U.S. 1 (1979). 
possible without a substantial foreclosure share in the tied market. ${ }^{149}$ Moreover, the Jefferson Parish opinion was written by Justice Stevens, who before becoming a justice was a well-known Chicago antitrust lawyer who actually taught at the University of Chicago and certainly understood its critique of tying doctrine. $\mathrm{He}$ did not miss this argument, but simply rejected it, concluding in his opinion that the quasi per se rule correctly focused on tying market power because of the economic effects that ties with such power could create even without a substantial tied foreclosure share.

Moreover, Jefferson Parish has been reaffirmed in other cases. In 1992, the Supreme Court once again held that tying was covered by the quasi per se rule in Kodak. The Kodak Court was clearly aware of the Chicago School critique. Indeed, the conservative justices in dissent referenced that critique, but specifically stated that, notwithstanding that critique, even they were sticking to the proposition that ties with market power were anticompetitive when they caused either foreclosure share effects or price discrimination and extraction effects. The dissenters stated:

Despite intense criticism of the tying doctrine in academic circles, see, e.g., R. Bork, The Antitrust Paradox 365-381 (1978), the stated rationale for our per se rule has varied little over the years. When the defendant has genuine "market power" in the tying product-the power to raise price by reducing output - the tie potentially enables him to extend that power into a second distinct market, enhancing barriers to entry in each. In addition: "[T]ying arrangements may be used . . . as a counting device to effect price discrimination; and they may be used to force a full line of products on the customer so as to extract more easily from him a monopoly return on one unique product in the line." For these reasons, as we explained in Jefferson Parish, "the law draws a distinction between the exploitation of market power by merely enhancing the price of the tying product, on the one hand, and by attempting to impose restraints on competition in the market for a tied product, on the other."150

Thus, even the conservative Kodak dissenters acknowledged that the "rationale" for the quasi per se rule was that ties with tying market power could have either foreclosure share effects or price discrimination and extraction effects. Moreover, the dissenters reaffirmed that it was because of "these reasons"-i.e., both of those

${ }^{149}$ Brief for the Petitioners, 1983 U.S. S. Ct. Briefs LEXIS 150, at *53-59.

150504 U.S. at 487 (Scalia, J., joined by O'Connor \& Thomas, JJ., dissenting) (quoting Fortner, 394 U.S. at 513-14 (White, J., dissenting)). 
sorts of effects - that antitrust law distinguishes between exploiting market power by simply raising the tying product price versus by using tying agreements.

Further, the conservative dissenters argued that the defendant's market power in Kodak was insufficient because it was not the sort of tying market power that "implicates the leveraging and price discrimination concerns behind the per se tying prohibition". ${ }^{151}$ Thus, even these conservative dissenters recognized that price discrimination concerns were behind the quasi per se rule. The dissenters further acknowledged that the quasi per se rule prohibits ties "when the manufacturer's monopoly power in the equipment, coupled with the use of derivative sales as 'counting devices' to measure the intensity of customer equipment usage, enabled the manufacturer to engage in price discrimination, and thereby more fully exploit its interbrand power." 152 The dissenters simply thought such market power was not present. Moreover, the dissenters also argued that even with tying market power, it was "unlikely that Kodak could have incrementally exploited" its market power in this harmful way because the tying and tied products had (the dissenters presumed) no separate utility and a fixed ratio. ${ }^{153}$ That premise was factually dubious, ${ }^{154}$ but if valid would indeed have disproven price discrimination and extraction effects. The key point here, however, is that the conservative dissenters felt obliged to disprove such price discrimination effects on the case facts because even they regarded the incremental exploitation of tying market power through such effects as anticompetitive.

In 2006, the Supreme Court once again confirmed that the quasi per se rule condemns unjustified ties with tying market power in Illinois Tool Works. Both in how it articulated the governing legal rule for tying and in its remand instructions, Justice Stevens' opinion for the Court made clear that liability turned on proof of tying market power without requiring any evidence of a substantial foreclosure share, which would have been implausible on the facts of that case. ${ }^{155}$ Moreover, the Court repeatedly made clear that it regarded this quasi per se rule as a form of rule of reason analysis "rather than" a per se rule because the quasi per se rule required evidence of tying market power and permitted evidence of procompetitive justifications. ${ }^{156}$ That is precisely the approach that I am defending.

${ }^{151}$ Id. at 494 .

${ }^{152}$ Id. at 499 (emphasis added).

${ }^{153} \mathrm{Id}$. at $492 \mathrm{n} .2$.

${ }^{154}$ The Court pointed out that both the tying and tied products were sometimes purchased without the other. Id. at 463 \& n.7 (majority opinion).

${ }^{155} 547$ U.S. at 36, 42-43, 46; Elhauge, Tying, supra note, at 425.

156547 U.S. at 42 ("we conclude that tying arrangements involving patented products should be evaluated under the standards applied in cases like ... Jefferson Parish rather than under the per se rule"); id. at 36 ("The 
Many critics claim that their legal position is confirmed by the recent Ninth Circuit decision in Brantley v. NBC Universal, Inc. ${ }^{157}$ However, Brantley is irrelevant because the court there deemed the plaintiffs to have waived any quasi per se theory of harm. ${ }^{158}$ Indeed, as the court read the complaint, the plaintiffs alleged no foreclosure at all because they alleged only the forced purchase of unwanted products that did not displace any purchases from a rival. ${ }^{159}$ Without the foreclosure of some sales, no claim lies even under the quasi per se rule, and indeed the situation fit within that rule's unwanted-product exception. The Brantley court thus never addressed the question whether the quasi per se rule still condemns unjustified ties when a significant dollar amount of foreclosure is alleged but a substantial foreclosure share is not. Nor did Brantley purport to question three prior Ninth Circuit cases that definitively held that facilitating price discrimination was an anticompetitive effect that justified the quasi per se rule against tying. ${ }^{160}$ To the contrary, Brantley favorably cited two of those cases. ${ }^{161}$ Even if it had purported to do so, the Brantley court had no authority to overrule

assumption that '[t]ying arrangements serve hardly any purpose beyond the suppression of competition,' rejected in Fortner II, has not been endorsed in any opinion since. Instead, it was again rejected just seven years later in Jefferson Parish, where, as in Fortner II, we unanimously reversed a Court of Appeals judgment holding that an alleged tying arrangement constituted a per se violation of $\S 1$ of the Sherman Act."); id. (describing Jefferson Parish as "rejecting the application of a per se rule" because it required proof of market power); id. at 45 (describing agencies and economists as rejecting the prior per se rule for tying and instead favoring the quasi per se rule approach of requiring proof of tying market power). Lambert incorrectly argues that other parts of Illinois Tool Works rejected the argument that price discrimination effects were anticompetitive. Lambert, supra note, at 933. However, the Court did no such thing. It simply rejected the proposition that showing price discrimination alone suffices to prove tying market power because the Court reasoned that price discrimination can often occur in competitive markets where market power is lacking. 547 U.S. at 44-45; see also Einer Elhauge, Why Above-Cost Price Cuts To Drive Out Entrants Are Not Predatory — and the Implications for Defining Costs and Market Power, 112 YALE L.J. 681, 732-43 (2003) (showing that price discrimination can occur without market power). This point hardly means that no anticompetitive effects are created by ties that do involve market power and have welfarereducing price discrimination effects. Nor is it plausible that Justice Stevens meant to overrule his own opinion in Jefferson Parish in such a cavalier fashion, especially since elsewhere in Illinois Tool Works he reaffirmed the Jefferson Parish position that unjustified ties with market power were anticompetitive. 547 U.S. at 36, 42-43, 46.

${ }^{157} 675$ F.3d 1192 (9 $9^{\text {th }}$ Cir. 2012); Carlton \& Waldman, supra note, at 11-12; Crane, supra note, at 27, 32-33; Lambert, supra note, at $953 \mathrm{n} .221$. I did some consulting for the plaintiffs in Brantley.

158675 F.3d at 1197 n.7.

${ }^{159}$ Id. at $1201,1203$.

${ }^{160}$ See Hirsh v. Martindale-Hubbell, Inc., 674 F.2d 1343, 1349 (9th Cir. 1982) ("First, tying arrangements are prohibited because they are thought to facilitate price discrimination."); The Mozart Co. v. Mercedes-Benz of North America, Inc., 833 F.2d 1342, 1345 n.3 (9th Cir. 1987) ("Tying arrangements are also viewed with disfavor because they can be used to facilitate price discrimination.”); Paladin Assocs., Inc. v. Montana Power Co., 328 F.3d 1145, 1159 n.14 (9th Cir. 2003) ("tying arrangements are harmful to competition" because, among other things, "they may be used as a counting device to effect price discrimination; and they may be used to force a full line of products on the customer so as to extract more easily from him a monopoly return on one unique product in the line." (quoting Fortner, 394 U.S. at 512-14 (White, J., dissenting).

${ }^{161} 675$ F.3d at 1197 n.7, 1200, 1203 
binding Supreme Court precedent like Jefferson Parish, Kodak, and Illinois Tool Works, which contradict the critics' position.

\section{Economics Supports the Supreme Court Distinction Between Exploiting Market Power by Pricing Versus by Tying}

Modern economics shows that the Supreme Court has been right to hold that a firm's entitlement to exploit its market power by setting a profit-maximizing price does not entitle it to use tying agreements to extract the remaining consumer surplus. What that modern economics proves is that firm incentives to invest in innovation or other productive efforts to generate market power will be optimal if firms receive only a fraction of the total surplus that lies under their demand curve. $^{162}$ This economic literature definitively disproves the critics' claim that it would increase welfare to allow firms to take $100 \%$ of that total surplus by extracting all consumer surplus.

The economic models are complex, but the intuition can be simply explained. Suppose our society creates an innovation with a total surplus of $\$ 1$ billion but spends \$1 billion to create it: what is the net gain? Zero, because we sacrificed value equal to what we got. As this simple example underscores, innovation creates net value only to the extent that consumers value the innovation by more than it cost to make it. Now, suppose we offer a prize of $\$ 1$ billion to any firm that creates that innovation: how much will firms spend to create it? The answer is that competing firms will spend up to $\$ 1$ billion. The result would be that we get innovation, but the innovation we get has zero net value. Thus, giving innovators $100 \%$ of total surplus is inefficient. Suppose instead we offer a prize of $\$ 0$ to any firm that creates an innovation? Then firms have no incentive to innovate, and we lose out on innovations that do have net value. Thus, giving innovators $0 \%$ of total surplus is also inefficient. Awarding a fraction that is between $0 \%$ and $100 \%$ will result in some net value, and there is some fraction that maximizes net value, thus resulting in an inverted $U$ curve. Accordingly, what we want to do is give innovators the fraction of total surplus that maximizes net value: i.e., that maximizes the difference between the value that consumers get from that innovation and the cost of creating that innovation. If we give less than that fraction, we will spend too little on innovation, but if we give more than that fraction, we will spend too much and thus get less net value from our innovations.

${ }^{162}$ See SUZANNE SCOTCHMER, INNOVATION AND INCENTIVES 100-03 (2004); Partha Dasgupta \& Joseph Stiglitz, Uncertainty, Industrial Structure, and the Speed of R\&D, 11 BELL J. ECON. 1, 18 (1980); Pankaj Tandon, Rivalry and the Excessive Allocation of Resources to Research, 14 BELL J. ECON. 152, 152, 156-57 (1983). 
How does our legal system set the fraction of total surplus to which firms are entitled? It does so by giving firms property rights when they invest in successful innovation or other productive activities like building a facility. When those property rights make the firm's product more valuable than the products of others, at least to some set of consumers, the firm will have a downward sloping firmspecific demand curve. The firm is then entitled to set the price for that product that maximizes its profits given that demand curve and to enjoy the resulting supracompetitive profits. Those profits are the fraction of total surplus to which they are entitled by property law. The profits at that profit-maximizing price are not $100 \%$ of total surplus because the consumers who value the product above that price get some consumer surplus. This consumer surplus is precisely what keeps firms from exceeding what property law has determined to be the optimal fraction.

To be sure, the economic literature does not establish that current property law has correctly set this fraction to match the optimal fraction. But we do know that the optimal fraction is less than $100 \%$ and thus requires allowing consumers to retain some surplus. This suffices to reject the critics' premise that $100 \%$ is the optimum and thus to reject their claim that we should allow firms to extract any additional consumer surplus they can by using tying agreements. It also makes sense for antitrust law to assume that other property laws have correctly set the optimum fraction. To the extent this assumption is true, allowing firms to exceed that fraction undermines optimal investment incentives. To the extent this assumption is not true, we cannot be sure whether property law is providing too big or small a fraction, and thus have no reason to allow firms to extract additional consumer surplus through tying. ${ }^{163}$ Nor would it be administrable to have courts adjudicate antitrust cases by having mini-trials on the optimality of property laws. Even if we had good evidence that the fraction set by property law was too low, the better remedy would be to reform those property laws, rather than to allow firms reap to higher profits for the subset of innovations where tying allows firms to exceed their normal profits, which will distort innovation towards those innovations even if they are less socially desirable than other innovations for which such ties are not feasible. ${ }^{164}$

Thus, modern economics clearly supports the Supreme Court's position that firms who earn their market power are entitled to the fraction of total surplus that they get by setting a profit-maximizing price using existing property rights, but are not

${ }^{163}$ See, e.g., Richard M. Brunell, Appropriability in Antitrust: How Much Is Enough?, 69 AnTITRUST L.J. 1, 4 (2001) (collecting literature).

${ }^{164}$ Grimes \& Sullivan, supra, note, at 352. 
entitled to extract the remaining consumer surplus through tying agreements. ${ }^{165}$ The critics are thus wrong to claim that this position requires rejecting the proposition that firms are entitled to normal monopoly profits from their innovation. ${ }^{166}$ This position instead simply recognizes that the entitlement of firms to normal profits does not allow firms to extract more than normal monopoly profits by restraining competition with tying agreements.

The contrary position of several critics, relying on a claim first made by Dennis Carlton and Ken Heyer, is that any restraint of trade (including tying) that increases the profits extracted from market power without increasing the degree of that power should be permitted even if it reduces consumer welfare and total welfare in the short run. ${ }^{167}$ They reason that such restraints of trade increase investment in the innovation that creates market power and assert that this increases both consumer welfare and total welfare in the long run. They thus conclude that ties without a substantial foreclosure share must increase welfare in the long run.

The problem is that Carlton and Heyer's claim depends on their mistaken premise that investments in innovation are suboptimal whenever firms "capture less than the total surplus created by their innovations," i.e., less than $100 \%$ of total surplus. ${ }^{168}$ Lambert recognizes this claim depends on that premise and makes the same assertion that: "Innovation ... tends to be retarded by the fact that innovators generally capture only a fraction of the surplus their efforts produce."169 They thus conclude that anything that increases the consumer surplus that firms can extract under their demand curve must be desirable because it necessarily brings firms closer to $100 \%$ of total surplus. But the economic literature mathematically proves that they have things precisely backwards: investments in innovation are optimal only if firms are limited to a fraction of the resulting total surplus. The critics simply never engage this literature or explain why they are denying the results of

${ }^{165}$ Elhauge, Tying, supra note, at 440 ("Patent holders are entitled to the normal monopoly profits they make by selling their patented goods, but are not currently entitled to extract more than those profits through tying.').

${ }^{166}$ Lambert, supra note, at 954; Semararo, supra note, at 32-33, 36.

${ }^{167}$ Carlton \& Heyer, supra note, at 290-92; Lambert, supra note, at 913-14, 953-59, 980; Semararo, supra note, at $30,36-37$.

${ }^{168}$ Carlton \& Heyer, supra note, at 291 n.12; see also id. at 285-86 (“An essential element of appropriate antitrust policy is to allow a firm to capture as much of the surplus that, by its own investment, innovation, industry, or foresight, the firm has itself brought into existence."); id. at 291 ("efficient investment incentives generally improve, the more surplus the firm is able to capture when its innovations create the surplus").

${ }^{169}$ Lambert, supra note, at 955. 
its mathematical proofs. ${ }^{170}$ Nor do they provide any analysis to support their assertion that the optimal fraction of total surplus to give to firms is $100 \%$.

Semararo acknowledges that "[s]ocially optimal investment requires that consumers share in the surplus generated by a new product," i.e., that the firms should get less than $100 \%$ of total surplus. ${ }^{171}$ However, he asserts that the Carlton and Heyer analysis on which he relies "cannot be criticized on this ground" because he claims their analysis "assumes that consumers would benefit sufficiently from future innovations to more than offset the short-run loss from higher prices." 172 He is wrong on this point because the reason that Carlton and Heyer make this assumption is precisely because they presume it is optimal to give a firm $100 \%$ of total surplus. Without that premise, one cannot justify their position that any conduct that extracts more consumer surplus from any given market power is always desirable. Nor does Semararo ever explain how he squares his assertion with the clear language from Carlton and Heyer that adopts precisely the premise that he acknowledges is surely wrong.

True, patents are limited in time, so a patentholder who extracted all of total surplus during the patent term would still get only some fraction of the overall total surplus. One could thus imagine a legal regime that set the optimal fraction by shortening the patent term on the assumption that patent holders could use ties to extract $100 \%$ of total surplus during the patent term. However, that is clearly not the legal regime in which we live because patent law itself condemns ties as patent misuses under standards that historically have made the patent illegality of ties extend beyond their antitrust illegality and that today continue to make patent illegality as broad or broader than antitrust illegality. ${ }^{173}$ Moreover, other property rights have indefinite or lengthy terms that make such an imaginary approach unfeasible and have anyway long been defined on the contrary assumption that unjustified ties with market power were illegal.

Carlton and Heyer suggest that their position might rest on the view that current patent law provides too little protection. ${ }^{174}$ But others believe that current patent

${ }^{170}$ Lambert instead essentially claims that firms often are not competing for positions of market power but instead are vying for different market niches. Id. at 956-59. But if the different market niches confer supracompetitive profits, it is not clear why he assumes that other firms would not compete for it. Moreover, it is clear that the quasi per se rule require some significant degree of market power, rather than the mere sort of brand differentiation that Lambert assumes. Compare id. at 958-59, with Illinois Tool Works, 547 U.S. at 44-45.

${ }^{171}$ Semararo, supra note, at 36.

${ }^{172}$ Id.

${ }^{173}$ X Phillip E. Areeda \& Herbert HovenKamp, Antitrust Law 520-30 (3rd ed. 2011).

${ }^{174}$ Carlton \& Heyer, supra note, at 292. 
law provides too much property protection. ${ }^{175}$ Even if one holds the former view, the better solution is to reform patent law to provide optimal incentives for all innovations, not to try to offset the problem imperfectly by modifying antitrust law to allow greater extraction of total surplus for the subset of innovations where tying is effective at achieving such extraction. Indeed, the latter strategy would distort investments towards those innovations for which tying is feasible, rather than towards those innovations that are the most socially valuable.

\section{CONCLUSION}

It would be better if we renamed the quasi per se rule what it actually is: one branch of a bifurcated rule of reason that correctly identifies the necessary conditions for certain types of anticompetitive effects, namely the tying market power and substantial dollar amount of tied sales that are necessary for extraction and price discrimination effects that significantly harm consumer welfare. The misnomer of calling this branch a quasi per se rule has unfortunately helped create a world where the dominant paradigm among antitrust defense lawyers and commentators mistakenly assumes that this tying doctrine fits within an overarching narrative of ill-considered per se rules. The dominance of this paradigm has left us in the remarkable situation where it is considered radical to argue that Supreme Court precedent should not be overruled.

As Thomas Kuhn observed, even top scholars have great difficulty accepting challenges to a paradigm, tending instead to dismiss contrary evidence and to prop up the dominant view with strained fudges, like the epicycles used to defend the once-dominant paradigm that the sun revolves around the earth. ${ }^{176}$ The effort to defend the dominant critical paradigm on tying has led to the antitrust equivalent of epicycles. It has led critics of tying law to use models with unrealistic discontinuities and assumptions to deny mathematical proofs that the normal distributions used in social science indicate that unjustified ties with market power typically reduce consumer welfare. It has led critics to leap from observations that ties can sometimes improve consumer welfare to unfounded assertions that they almost always do. It has led critics to try to change the metric to total welfare, even though consumer welfare is the clear legal standard and proofs show that total welfare likely decreases as well. It has led critics to deny that requirements ties exist outside of gangster life, even though they were at issue in seven Supreme Court cases. It has led critics to argue that the quasi per se rule excludes

\footnotetext{
${ }^{175}$ Ian Ayres \& Gideon Parchomovsky, Tradable Patent Rights, 60 STAN. L. REV. 863, 864 (2007).

176 Thomas KuHN, the Structure OF SCIENTIFIC ReVolutions (1962).
} 
procompetitive justifications even though they themselves in other writings assert the opposite. It has led critics to claim that precedents require overturning themselves and that the principle that antitrust protects competition not competitors instead means precisely the opposite. It has led critics to deny that restraints on competition that harm welfare count as anticompetitive, and to argue that certain theories do not count as anticompetitive even when they were cited by the Supreme Court to explain why it deems ties with tying market power to be anticompetitive. Finally, it has led critics to insist that the right to earn ordinary monopoly profits through pricing is indistinguishable from a right to extract all remaining consumer surplus through tying, even though both legal precedent and economic proofs reject that claim.

This is not to say that one could not make legitimate policy objections about the current state of tying doctrine. As noted above, if a tie involves products that both have a fixed ratio and lack separate utility, then it cannot create extraction or price discrimination effects and thus the quasi per se rule should not apply. Although as noted above, court decisions are consistent with this exception and have hinted at it, they have not yet explicitly stated this exception exists; doing so would create useful clarity for an important set of ties. Further, the Supreme Court may have too strong a presumption against justifications, in some cases rejecting them based on supposed less restrictive alternatives without considering the incentive and monitoring cost problems that those alternatives raised. But we should refocus the debate on the legitimate issues raised by the doctrine we actually have, rather than on red herrings and attacks on straw man claims about that doctrine. 


\section{APPENDIX}

\section{Proof that With a Normal Bell-Shaped Distribution, Metering Ties Reduce Consumer Welfare, and Also Reduce Total Welfare Unless Desired Usage Rates Are Highly Dispersed and Profit Dissipation Rates Are Very Low}

Assume a market with a capital good whose usage requires using a consumable good used with it, like using ink with a printer. The capital good and consumable each have a marginal cost of zero. The value of each usage of the capital good used is $v$, which varies linearly from 0 to $A$ for different consumers. However, some consumers use the capital good more often than others and thus use more consumables. Consumers of type $n$ would use $n$ units of consumable with the capital good at the competitive price for the consumable, where $n$ goes from 0 to $2 M$. Instead of assuming that the number of consumable units the consumers would use is distributed uniformly, assume more realistically that it evidences a normal bell-shaped distribution, where the mean is $M$ and the standard deviation is $S M$, where $S$ is the share of the mean made up by the standard deviation. Given a normal distribution, the proportion of customers who will use $n$ units equals $\frac{1}{S M \sqrt{2 \pi}}$ $e^{-\left(\frac{1}{2}\right)\left(\frac{n-M}{S M}\right)^{2}}$, as $n$ goes from 0 to $M$.

Without Tying. The consumable is priced at zero without tying. A customer of type $n$ will buy the capital good at price $p$ only if the number of times they would use the product exceeds the price divided by the value per usage, that is if $n \geq p / v$. Because the highest valuation per usage is $A$, the lowest $n$ will be $p / A$ for any purchaser who buys the capital good sold at price $p$. Because the highest usage is $2 M$, the highest possible price to sell the capital good is $2 M A$, and the highest possible value for $p / A=2 M$. Because $v$ varies linearly from 0 to $A$ for different consumers, the total quantity of the capital good sold to type $n$ customers will be $(1 / A)(A-p / n)$. Profits from type $n$ customers will be this quantity times price $p$, or $(p / A)(A-p / n)=p-p^{2} / A n$. Total profits will be the integral of this function times the probability that customers are at each $n$ level. Thus total profits equal

$$
\Pi=\int_{p / A}^{2 M}\left(p-p^{2} / A n\right)\left(\frac{1}{S M \sqrt{2 \pi}}\right) e^{-\left(\frac{1}{2}\right)\left(\frac{n-M}{S M}\right)^{2}} d n
$$

Profits are maximized when the derivative of total profits equals zero, which is when 
$d \Pi / d p=\int_{p / A}^{2 M}(1-2 p / A n)\left(\frac{1}{S M \sqrt{2 \pi}}\right) e^{-\left(\frac{1}{2}\right)\left(\frac{n-M}{S M}\right)^{2}} d n=0 .{ }^{177}$

Integrating and using $\mathrm{z}$ as a shorthand for $p / A$, this equation equals

$\left(\frac{1}{2}\right) \operatorname{erf}\left(\frac{1}{S \sqrt{2}}\right)-\left(\frac{1}{2}\right) \operatorname{erf}\left(\frac{z-M}{S M \sqrt{2}}\right)-\left(\frac{2 z}{S M \sqrt{2 \pi}}\right) \int_{z}^{2 M}(1 / n) e^{-\left(\frac{1}{2}\right)\left(\frac{n-M}{S M}\right)^{2}} d n=0$.

This does not reduce further mathematically, but we can solve numerically for a range of possible values for $S$, the share of the median made up by the standard deviation.

Suppose, for example, the standard deviation for buyer usage rates is $20 \%$ of the mean (i.e., $\mathrm{S}=.2$ ), so the bell-shaped curve has the following typical shape. (By way of comparison, the standard deviation in IQ is $15 \%$ of the mean of 100 and for US men's height it is $4 \%$ of the mean of 70 inches, which would mean a more narrow peak in the middle.)

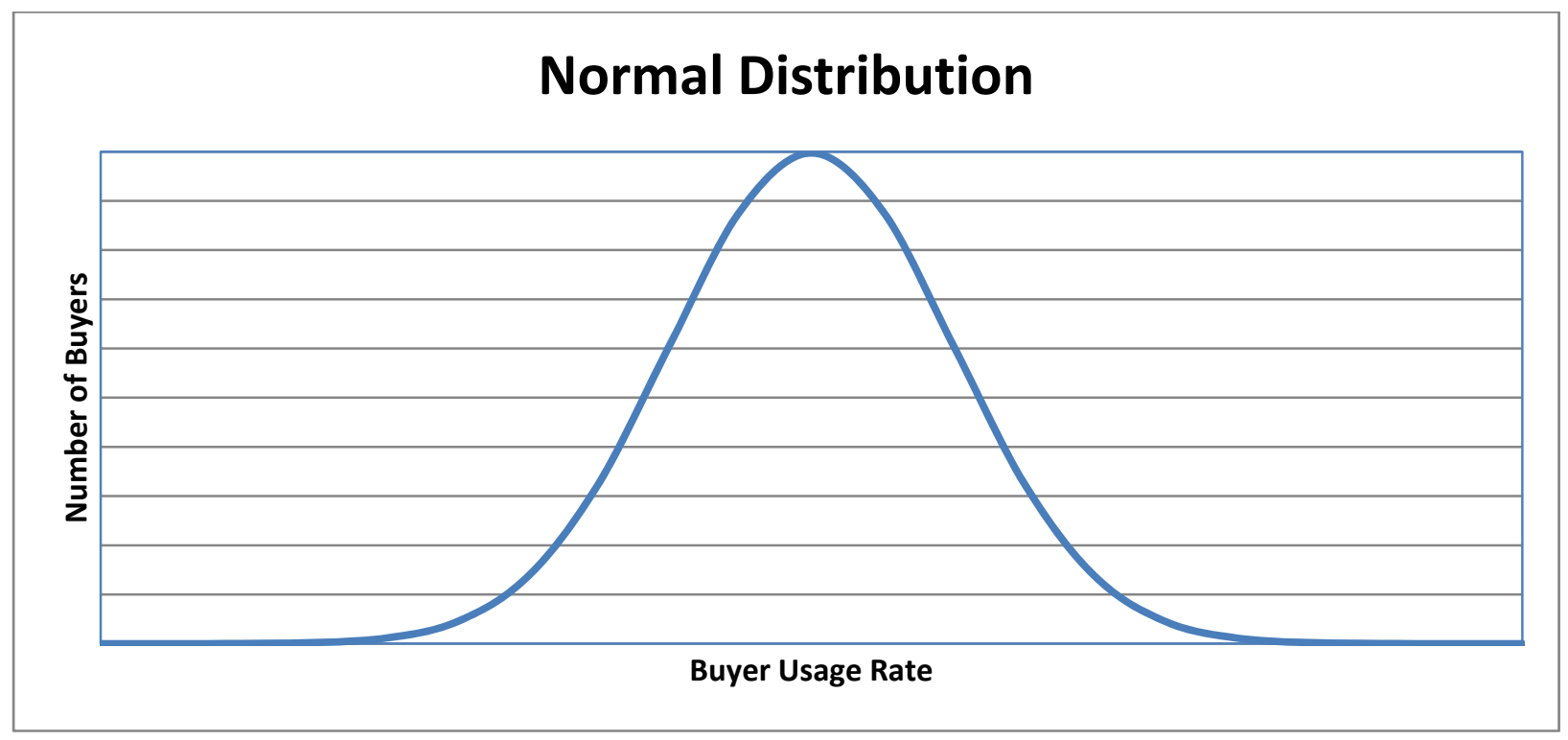

Solving numerically, with $\mathrm{S}=.2$, profits are maximized when $z=.48 M$. Thus, without tying the firm will set a price for the capital good of .48MA that equals .48 times the mean usage times the maximum value per usage, and the capital good will not be sold to any purchasers who use it less than $.48 M$ times.

${ }^{177}$ This is the first order condition, but we know it is a maximum because the second derivative with respect to $p$ is negative. 
Plugging this price into the formula above for total profits, we find that total profits will be

$$
\begin{aligned}
\Pi & =\int_{.48 M}^{2 M}\left(.48 M A-(.48 M)^{2} A / n\right)\left(\frac{1}{.2 M \sqrt{2 \pi}}\right) e^{-\left(\frac{1}{2}\right)\left(\frac{n-M}{.2 M}\right)^{2}} d n \\
& =.24 M A \text { times however many potential customers there are. }
\end{aligned}
$$

Total consumer surplus without tying is $\int_{p / A}^{2 M}\left(\frac{n}{2 A}\right)\left(A-\frac{p}{n}\right)^{2}\left(\frac{1}{S M \sqrt{2 \pi}}\right) e^{-\left(\frac{1}{2}\right)\left(\frac{n-M}{S M}\right)^{2}} d n$.

Thus, at the profit-maximizing price of . $48 M A$ and a standard deviation of $.2 M$ this will be

$$
\begin{aligned}
& \int_{.48 M}^{2 M}(n / 2 A)\left(A-\frac{.48 M A}{n}\right)^{2}\left(\frac{1}{.2 M \sqrt{2 \pi}}\right) e^{-\left(\frac{1}{2}\right)\left(\frac{n-M}{.2 M}\right)^{2}} d n \\
& =.14 A M \text { times the number of potential customers. }
\end{aligned}
$$

Total welfare is the sum of profits and consumer surplus, thus it will be $.38 A M$ without tying.

Given the zero cost of producing the capital good, the total output of capital goods sold will equal the profits on sales of the capital good divided by its price, and thus comes to 0.50 times the number of potential customers.

The total output of consumables will be

$$
\int_{p / A}^{2 M}\left(\frac{n}{A}\right)\left(A-\frac{p}{n}\right)\left(\frac{1}{S M \sqrt{2 \pi}}\right) e^{-\left(\frac{1}{2}\right)\left(\frac{n-M}{S M}\right)^{2}} d n
$$

Thus, given a price of .48MA and standard deviation of .2M, this comes to

$$
\int_{.48 M}^{2 M}\left(\frac{n}{A}\right)\left(A-\frac{.48 M A}{n}\right)\left(\frac{1}{.2 M \sqrt{2 \pi}}\right) e^{-\left(\frac{1}{2}\right)\left(\frac{n-M}{.2 M}\right)^{2}} d n
$$


$=.52 \mathrm{M}$ times the number of potential customers.

Thus, consumers will on average use $1.04 M$ units of the consumable for each capital good purchased.

With Tying. With tying, the tying firm will maximize profits by selling the capital good at a price of zero tied to the consumable at a price of $A / 2$ each. Half of the consumers in each $n$th group will buy a printer for zero and pay $n \mathrm{~A} / 2$ for their $n$ consumables. Thus, total profits with tying will be

$$
\int_{0}^{2 M}(A / 4) n\left(\frac{1}{S M \sqrt{2 \pi}}\right) e^{-\left(\frac{1}{2}\right)\left(\frac{n-M}{S M}\right)^{2}} d n
$$

Given the assumed standard deviation of .2M, this comes to

$$
\begin{aligned}
& \int_{0}^{2 M}(A / 4) n\left(\frac{1}{.2 M \sqrt{2 \pi}}\right) e^{-\left(\frac{1}{2}\right)\left(\frac{n-M}{.2 M}\right)^{2}} d n \\
& =.25 A M
\end{aligned}
$$

Thus, the firm will tie because tying increases its profits from $.24 A M$ to $.25 A M$, an increase of $4 \%$.

The half of the consumers in each nth group that buy a printer will get a total of $n \mathrm{~A} / 4$ surplus on $n$ units. Thus, total consumer surplus with tying will be half of total profits, or .125AM. Thus, as in the model with a uniform distribution, tying still reduces consumer welfare, from .14AM to .125AM, which is by $11 \%$.

Total surplus with tying will be the sum of total profits and consumer surplus = $.375 A M$. Thus tying will reduce total welfare from $.38 A M^{2}$ to $.375 A M$, which is by $1 \%$.

Total output of the consumable will be the profits on sales of the consumable divided by its price of $.5 \mathrm{~A}$, which comes to $.5 \mathrm{M}$. This means that total output of the consumable - which is the same as total usage of the capital good - will decline from $.52 M$ to $.5 M$, which is a $4 \%$ drop.

Half of the buyers in each group will buy the capital good. Thus, the output of capital goods will be 0.5 . So the output of capital goods will be unchanged. But 
usage per each capital good will be 1.0 units, a 4\% drop from the 1.04 units per capital good used without a tie, which results because of the higher price on the consumable.

Other Standard Deviations. Using the same method as used above for $\mathrm{S}=$ .2 , we can derive the above figures for any standard deviation. Doing so produces the figures reported below in Table 1.

\begin{tabular}{|c|c|c|c|c|c|c|c|}
\hline \multicolumn{6}{|c|}{ Table 1. Immediate Welfare Effects of Ties That Create Intra-product Price } \\
Discrimination (With a Normal Distribution of Buyer Usage and Zero Dissipation Costs) \\
\hline $\begin{array}{c}\text { Standard } \\
\text { Deviation } \\
\begin{array}{c}\text { Share of } \\
\text { Mean }\end{array}\end{array}$ & $\begin{array}{c}\text { Profit } \\
\text { Change }\end{array}$ & $\begin{array}{c}\text { Consumer } \\
\text { Welfare } \\
\text { Change }\end{array}$ & $\begin{array}{c}\text { Total } \\
\text { Welfare } \\
\text { Change }\end{array}$ & $\begin{array}{c}\text { Capital } \\
\text { Output } \\
\text { Change }\end{array}$ & $\begin{array}{c}\text { Tied } \\
\text { Output } \\
\text { Change }\end{array}$ & $\begin{array}{c}\text { Change } \\
\text { in Usage } \\
\text { Per } \\
\text { Capital } \\
\text { Good }\end{array}$ & $\begin{array}{c}\text { Profit } \\
\text { Dissipation } \\
\text { Needed to } \\
\text { Reduce } \\
\text { Total } \\
\text { Welfare }\end{array}$ \\
\hline $10 \%$ & $+1.0 \%$ & $-2.6 \%$ & $-0.2 \%$ & $+0.2 \%$ & $-0.8 \%$ & $-1.0 \%$ & $0 \%$ \\
\hline $20 \%$ & $+4.4 \%$ & $-11.0 \%$ & $-1.3 \%$ & $+0.3 \%$ & $-3.9 \%$ & $-4.2 \%$ & $0 \%$ \\
\hline $30 \%$ & $+9.5 \%$ & $-16.7 \%$ & $-0.9 \%$ & $+4.3 \%$ & $-5.4 \%$ & $-9.3 \%$ & $0 \%$ \\
\hline $40 \%$ & $+14.0 \%$ & $-19.8 \%$ & $-0.04 \%$ & $+11.7 \%$ & $-5.8 \%$ & $-15.7 \%$ & $0 \%$ \\
\hline $50 \%$ & $+17.0 \%$ & $-21.0 \%$ & $+0.9 \%$ & $+21.9 \%$ & $-5.6 \%$ & $-22.6 \%$ & $1.2 \%$ \\
\hline $60 \%$ & $+18.9 \%$ & $-21.2 \%$ & $+1.7 \%$ & $+34.1 \%$ & $-5.2 \%$ & $-29.3 \%$ & $2.4 \%$ \\
\hline $70 \%$ & $+20.1 \%$ & $-21.0 \%$ & $+2.3 \%$ & $+47.7 \%$ & $-4.7 \%$ & $-35.5 \%$ & $3.3 \%$ \\
\hline $80 \%$ & $+20.8 \%$ & $-20.7 \%$ & $+2.8 \%$ & $+62.3 \%$ & $-4.3 \%$ & $-41.0 \%$ & $4.0 \%$ \\
\hline $90 \%$ & $+21.3 \%$ & $-20.4 \%$ & $+3.2 \%$ & $+77.6 \%$ & $-3.9 \%$ & $-45.9 \%$ & $4.6 \%$ \\
\hline $100 \%$ & $+21.6 \%$ & $-20.3 \%$ & $+3.5 \%$ & $+93.1 \%$ & $-3.7 \%$ & $-50.1 \%$ & $4.9 \%$ \\
\hline
\end{tabular}

As Table 1 shows, metering ties are always profitable to the firm, giving it a powerful motivation to tie. However, the effects on consumer welfare are uniformly negative. The immediate effects on total welfare are also negative unless the bell curve of desired buyer usage rates is fairly flat, with a standard deviation that exceeds $40 \%$ of the mean.

Further, the total welfare change reported in fourth column Table 1 reports only the immediate effects after a tie if we assume zero implementation costs, zero agency costs, and zero ex ante costs. In reality, all three of those costs are likely to dissipate some or all of the profit increase, thus reducing total welfare. ${ }^{178}$ The last column of Table 1 reports the minimum profit dissipation rate that would suffice to make a metering tie harmful to full total welfare.

${ }^{178}$ See supra at 